\title{
GUÍAS ESQUEMATIZADAS DE TRATAMIENTO DE LOS TRASTORNOS DE LA PERSONALIDAD PARA PROFESIONALES, DESDE EL MODELO DE BECK, FREEMAN, DAVIS Y OTROS (2005)
}

\author{
SCHEMATIC-GUIDES FOR PROFESSIONALS TO TREAT PERSONALITY \\ DISORDERS, FROM THE MODEL OF BECK, FREEMAN, DAVIS AND OTHERS (2005)
}

\author{
Andrés Fernando López Pell \\ Universidad Católica de Santa Fe, Argentina \\ Juan Manuel Rondón \\ Universidad Católica de Santa Fe, Argentina \\ Cecilia Cellerino \\ Universidad Católica de Santa Fe, Argentina \\ Silvina María Alfano \\ Universidad Católica de Santa Fe, Argentina
}

\begin{abstract}
Resumen: Los tratamientos psicológicos para los Trastornos de la personalidad todavía no alcanzan un grado de protocololarización tan específico como para describir las intervenciones para cada sesión. Esto podría deberse a la heterogeneidad de los casos que dificultaría la posibilidad de diseñar un protocolo. Los tratamientos entonces se basan en conceptualizaciones de caso sustentadas teóricamente que después determinan los objetivos y las intervenciones a realizar. La dificultad para conceptualizar desde determinado modelo puede que sea una razón por la que a los psicoterapeutas les costaría realizar el tratamiento más adecuado. Para afrontar este problema hemos diseñado unas 'Guías esquematizadas para profesio-nales’ para mejorar la práctica de la psicoterapia para los trastornos y alteraciones de la personalidad. Estas guías son de una carilla para tenerlas a la vista durante las sesiones a fin conceptualizar los casos y guiar más fácilmente las inter-venciones desde el modelo de Beck, Freeman, Davis y otros (2005).
\end{abstract}

Palabras clave: Personalidad, trastornos, tratamiento, cognitivismo.

\begin{abstract}
Psychological treatments for personality disorders have not yet reached a level of protocol as specific as to describe inter-ventions for each session. This could be due to the heterogeneity of cases that make it difficult to design a protocol. Treatments are then based on case conceptualizations supported by theories that determine the objectives and interven-tions performed. The difficulty to conceptualize from a particular model may be a reason that psychotherapists find prob-lems to make the most appropriate treatment. Addressing this problem, we have designed 'Professional schematic-guides' to improve the practice of personality disorders psychotherapy. These one-page-guides were created to have them in front of you during the sessions, to conceptualize cases and easily guide the interventions from the model of Beck, Freeman, Davis and others (2005).
\end{abstract}

Keywords: Personality, disorders, treatment, cognitivism.

\section{INTRODUCCIÓN}

Nada ha demostrado ser más eficaz que la aplicación de un protocolo psicoterapéutico científicamente validado. Sin embargo ¿qué hacer cuando el paciente tiene varios trastornos?, o ¿cuándo no hay un protocolo validado para tratar el trastorno que sufre? En tales circunstancias, una opción es basar el tratamiento en una conceptualización de sus problemas guiada por el marco teórico cognitivo. 
La formulación del caso tiene implicancias para el desarrollo del diseño del tratamiento y consecuentemente para la elección de las intervenciones más apropiadas para el logro de los fines terapéuticos. Cuando se trata de práctica manualizada la psicoterapia para los trastornos y alteraciones de la personalidad no se encuentra a la vanguardia. Si bien existen libros de cabecera que guían el tratamiento (e.g., Beck, Freeman, Davis y otros, 2005), todavía no ha alcanzado un grado de protocololarización tan específico como para describir las intervenciones para cada sesión. Más bien se basan en conceptualizaciones de caso sustentadas en formulaciones teóricas que después determinan los objetivos y las intervenciones a realizar durante el tratamiento. Esta ha sido una tendencia claramente marcada en los modelos de abordaje de estos trastornos en los últimos años (e.g., Beck, Freeman, Davis \& otros; Millon \& Davis, 1998; Young, Klosko \& Weishaar, 2003).

\section{La dificultad para conceptualizar desde} determinado modelo puede que sea una la las tantas razones del por que a los psicoterapeutas les cueste más seguir las pautas descriptas en estos textos para el abordaje de estas alteraciones. Otra cuestión de suma importancia en torno a la protocolarización de la psicoterapia para los Trastornos de la personalidad es que son pacientes muy difíciles de mantener en tratamiento por lo cual se requiere de mucha flexibilidad por parte del terapeuta. Esto, sumado a la heterogeneidad de los casos, dificulta la posibilidad de diseñar un protocolo de tratamiento de alta especificidad delineado para cada sesión como existe para otros trastornos (e.g., depresivo mayor, de angustia, ansiedad generalizada, etc.) ya que cada tratamiento, si bien es guiado por la misma base teórica, termina adquiriendo una forma particular.

Los autores de este artículo hemos conformado un equipo de investigación que en los últimos años se ha dedicado a la optimización de la psicoterapia. En busca de enfrentar la problemática planteada en los párrafos anteriores hemos diseñado unas 'Guías esquematizadas para profesionales' para mejorar la práctica de la psicoterapia para los trastornos y alteraciones de la personalidad. Estas guías fueron realizadas en una carilla cada una con la idea que los psicoterapeutas las tengan a la vista durante las sesiones y que de esta manera puedan conceptualizar sus casos y guiar más fácilmente sus intervenciones. Atento a estas cuestiones en este artículo presentaremos los conceptos centrales que deben guiar la praxis desde el modelo de Beck, Freeman, Davis y otros (2005) de de una manera simple y comprensible a fin de facilitar la transferencia del conocimiento al set psicoterapéutico.

\section{TEORÍA DE LA PERSONALIDAD}

Aaron Beck forma parte del primer grupo de terapeutas cognitivos que se dedicaron a sistematizar tratamientos específicos para diversas patologías, incluidos los trastornos de la personalidad. Su trabajo permitió una sistematización del efecto terapéutico de las técnicas cognitivas sobre las estructuras sintomáticas, focalizadas en los esquemas cognitivos o creencias controladoras. Tales esquemas proporcionan las instrucciones que guían el centro, la dirección y las cualidades de la vida diaria, así como las contingencias especiales (Beck, Freeman, Davis et al, 2005).

Hasta 1990 aproximadamente, la bibliografía preponderante sobre el abordaje de los trastornos de personalidad correspondía al psicoanálisis. Los teóricos cognitivos comparten con los psicoanalistas la idea de que en el tratamiento de los trastornos de la personalidad es, por lo general, más productivo identificar y modificar los problemas nucleares. Los dos enfoques difieren en su visión de la naturaleza de la estructura nuclear; para la escuela psicoanalítica, esas estructuras son inconscientes y no fácilmente accesibles para el paciente (Ingram \& Hollon, 1986). Desde el punto de vista cognitivo, los productos de ese proceso son en gran medida conscientes $y$, con un entrenamiento especial, aún pueden resultar más accesibles a la conciencia. Además, los sentimientos y las conductas disfuncionales se deben en gran medida a la función de ciertos esquemas que tienden a producir sistemáticamente juicios tendenciosos y una predisposición asociada a cometer errores en determinadas situaciones. La premisa básica del modelo de la terapia cognitiva es que la fuente principal del afecto y la conducta disfuncionales en los adultos reside en la distorsión atributiva, y no en la distorsión motivacional o de respuesta (Beck et al, 2005). 


\section{Características del paciente y del tratamiento para trastornos de la personalidad}

Beck et al (2005), señalan que, en su mayoría, los pacientes con trastornos de personalidad suelen no darse cuenta de cómo llegaron a ser lo que son, cómo contribuyen a crear sus propios problemas, y tampoco saben cómo cambiar. Esto se debe a la tenacidad de los esquemas disfuncionales, ya que operan desde un largo período de tiempo. Aún más, los esquemas de acción que el terapeuta conceptualiza como un trastorno de personalidad pueden haber sido funcionales para el sujeto en muchas situaciones vitales, sobre todo a corto plazo. Así es muy probable que éstos pacientes acudan a terapia por motivos ajenos a problemas de los que en el DSM se categorizan en el Eje II (APA, 1995); usualmente consultan por quejas de depresión, ansiedad o situaciones externas que los empujan a buscar ayuda. Los autores indican que los signos heurísticos que pueden revelar la posibilidad de que un paciente presente problemas del Eje II son los siguientes:

- $\quad$ El paciente o un conocido informa que siempre se ha comportado de esa manera.

- $\quad$ No acepta el régimen terapéutico.

- La terapia parece llegar a una interrupción súbita, sin razón aparente. Sobre todo al reducirse los problemas de ansiedad o angustia por los que usualmente consultan.

- $\quad$ No parecen tener conciencia del efecto de su conducta sobre los demás.

- $\quad$ Expresa voluntad de cambio, pero no sigue las prescripciones.

- Ve los problemas como aspectos fundamentales de su 'yo', le parecen aceptables y naturales.

Respecto al tratamiento, Beck (1985) considera que es importante tener conciencia que la terapia provocará ansiedad, ya que se modificará la identidad del paciente y el sentido de su yo. Por más incómodos, limitantes y solitarios que puedan ser sus esquemas de acción, el cambio implica entrar en un nuevo y extraño territorio: no sólo se les pide que cambien una parte de su cadena conductual o que reencuadren una simple percepción, sino que renuncien a lo que son y a cómo se han definido a sí mismos durante muchos años y muchos contextos. Es fundamental entonces:
- $\quad$ Un alto grado de acuerdo entre las expectativas del paciente acerca de las metas y objetivos terapéuticos y las del terapeuta.

- Un estilo tranquilo y seguro por parte del terapeuta.

- Una naturaleza cooperativa durante el proceso de establecimiento de metas.

- Enfocar estrategias de modo tripartito, atendiendo las áreas cognitiva, conductual y afectiva. Para ello, se deben usar los tres componentes terapéuticos: cognitivo, expresivo y relacional.

\section{Teoría de los trastornos de la personalidad}

La terapia cognitiva de cualquier trastorno depende de la conceptualización de éste último y su adaptación a las características únicas de un caso específico. Beck et al (2005), presentan una teoría de los trastornos de la personalidad centrada inicialmente en la formación de los procesos de la personalidad y la operación de los mismos al servicio de la adaptación, basada en la hipótesis de que los prototipos de nuestras pautas de personalidad pueden derivarse de la herencia filogenética. Las estrategias genéticamente determinadas que facilitaron la supervivencia y la reproducción fueron presumiblemente favorecidas por la selección natural. Pueden observarse derivados de esas estrategias primitivas en los síndromes sintomáticos de los trastornos de la personalidad (i.e., trastorno por dependencia).

Ahora bien, según Beck et al (2005), ante una situación específica, el procesamiento de la información, que incluye los procesos afectivos, precede a la puesta en práctica de dichas estrategias: la evaluación de las exigencias particulares de una situación es anterior y desencadena una estrategia adaptativa o inadaptada. La manera de evaluar una situación depende por lo menos en parte de las creencias subyacentes pertinentes. Esas creencias están insertadas en estructuras más o menos estables, denominadas esquemas, que seleccionan y sintetizan los datos que ingresan. La secuencia psicológica pasa entonces de la evaluación a la activación afectiva y motivacional, y finalmente a la selección e instrumentación de la estrategia pertinente. En otras palabras, los procesos cognitivos, afectivos y motivacionales dependen de los esquemas, unidades fundamentales de la personalidad. 
A título de resumen, la Figura 1 ilustra de manera integrada el modelo cognitivo de Beck (1995), sistematizando los conceptos característicos de la teoría del mismo:

Los rasgos de la personalidad pueden conceptualizarse como expresiones abiertas de estas estructuras subyacentes (i.e., esquemas). Al asignar significados a los acontecimientos, las estructuras cognitivas inician una reacción en cadena que culmina en los tipos de conducta abierta (i.e., estrategias) que se atribuyen a los rasgos de la personalidad. Las pautas conductuales que comúnmente se adscriben a los rasgos o disposiciones de la personalidad (i.e., honesto, tímido, sociable), representan estrategias interpersonales desarrolladas a partir de la interacción entre las disposiciones innatas y las influencias ambientales. Los atributos de la personalidad de cada rasgo se consideran como estrategias básicas -en términos conductuales y funcionales-, y son funciones de conglomerados de esquemas básicos. En los trastornos de personalidad, estas estrategias se presentan hiperdesarrolladas, en detrimento de otras, que están infradesarrolladas (Beck et al, 2005).

Para una mejor comprensión de lo enunciado cabe hacerse la siguiente pregunta: ¿cómo se activan los esquemas en relación a los trastornos de personalidad?
Las creencias disfuncionales típicas y las estrategias mal adaptadas que se expresan en trastornos de la personalidad hacen a los individuos sensibles a experiencias vitales que inciden en su vulnerabilidad cognitiva. Esta vulnerabilidad se basa en creencias extremas, rígidas e imperativas. En un terreno especulativo, la teoría de la personalidad de Beck postula que esas creencias disfuncionales se originan en la interacción de la predisposición genética del individuo con su exposición a influencias indeseables de otras personas y a hechos traumáticos específicos.

En relación a las estrategias, Gilbert (1989) entiende que la selección natural haya generado algún tipo de ajuste entre la conducta programada y las exigencias del ambiente. Pero nuestro ambiente ha cambiado con más rapidez que nuestras estrategias adaptativas automáticas $\mathrm{y}$, consecuentemente, se producen inadecuaciones entre ambos. A su vez, una inadecuación puede ser un factor en el desarrollo de la conducta que diagnosticamos como trastornos de la personalidad, sobre todo si las pautas son inflexibles y relativamente incontroladas. Por ejemplo, las estrategias predatorias primitivas de supervivencia quizá no se adecuen al medio social y desemboquen en un trastorno antisocial de la personalidad.

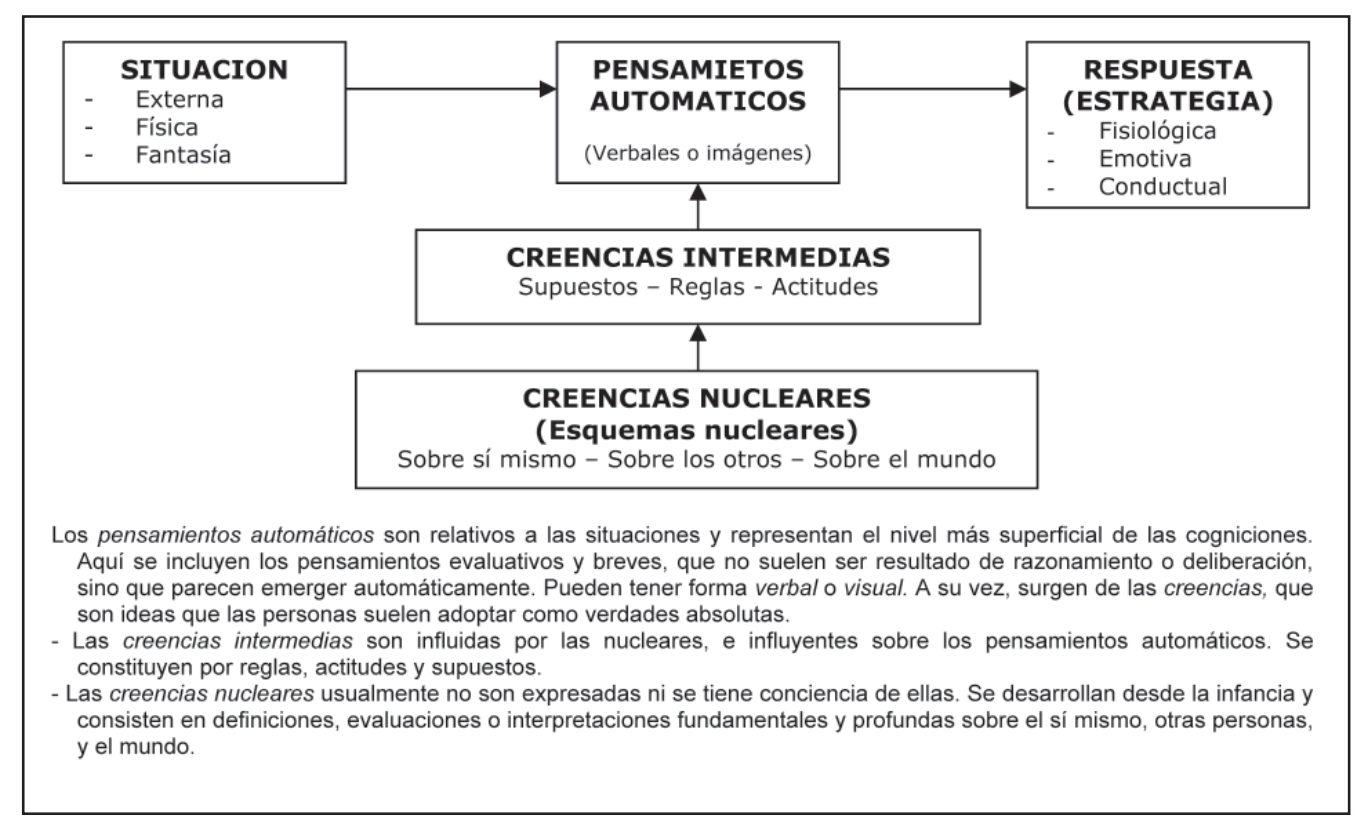

Figura 1. Esquema del modelo cognitivo de Beck, en base a Obst Camerini (2008) 
Debe tenerse en cuenta que en este sentido evolutivo las estrategias se consideran como formas de conducta programada destinadas a servir metas biológicas. Si bien el término implica un plan racional y consciente, aquí se emplea como lo hacen los etólogos, para indicar conductas estereotipadas, altamente pautadas, favorables a la supervivencia individual y a la reproducción.

En los seres humanos, el término 'estrategia' puede aplicarse análogamente a formas de conducta que pueden ser adaptativas o inadaptadas, según las circunstancias. Debido a que sólo se puede observar la conducta externa, surge el planteo de cómo se relacionan los estados internos (i.e., pensamientos, sentimientos y deseos) con las estrategias. Un modo de ilustrar esta relación consiste en examinar los procesos exagerados que se observan en individuos con diversos trastornos de la personalidad, y comparar las actitudes típicas específicas asociadas a esos desórdenes con las estrategias correspondientes.

En la Tabla 1 se exponen los trastornos de la personalidad junto a las actitudes correspondientes de cada uno -que subyacen en la conducta manifiesta- y a las estrategias específicas (i.e., pauta conductual indiosincrásica). Esta tabla no incluye el trastorno límite ni el esquizotípico, puesto que estos no presentan un conjunto indiosincrásico típico de creencias y estrategias.

\section{Interacción entre lo genético y lo interper- sonal}

La teoría de Beck se apoya en la psicología evolutiva, puesto que reconoce que existen temperamentos y pautas conductuales relativamente estables desde el nacimiento (Kagan, 1989). Pero dichas características innatas son reconocidas como 'tendencias' que la experiencia puede acentuar o atemperar. Además, entre las pautas innatas de un individuo y las de otras personas significativas puede establecerse un ciclo continuo de refuerzo recíproco. Pero, hasta aquí, ni las tendencias innatas ni la conducta podrían explicar las diferencias individuales.

En efecto, son los programas integrados cognitivo-afectivo-motivacionales los que deciden la conducta del individuo y lo distinguen como tal. Las experiencias de las personas, sus relaciones con el contexto y otras personas, fijan en ellas creencias. Beck et al (2005) enfatizan en que si bien las creencias pueden fijarse por repeticiones de experiencias traumáticas (i.e., combinación de predisposiciones innatas e influencias ambientales), algunos individuos logran cambiar su conducta y modificar actitudes subyacentes. Bajo la formulación de esta teoría, cada individuo tiene un perfil único de personalidad, que consiste en los diversos grados de probabilidad de que responda de cierto modo a cierto grado de una situación particular.

Tabla 1. Creencias básicas y estrategias asociadas con los trastornos tradicionales de la personalidad. En base a Beck et al (2005)

\begin{tabular}{|c|c|c|}
\hline Trastorno de la personalidad & Creencias/actitudes básicas & $\begin{array}{c}\text { Estrategia } \\
\text { (conducta manifiesta) }\end{array}$ \\
\hline Por dependencia & 'Estoy desvalido'. & Apego \\
Por evitación & 'Pueden hacerme daño'. \\
Pasivo-agresivo & 'Podría ser dominado'. \\
Paranoide & 'La gente es peligrosa'. & Resistencia \\
Narcisista & 'Soy especial'. & Cautela \\
Histriónico & 'Necesito impresionarles'. & Autoexaltación \\
Obsesivo-compulsivo & 'Los errores son malos, no debo & Dramatismo \\
Antisocial & equivocarme'. & Perfeccionismo \\
Esquizoide & 'Los demás están para dominarlos'. & Ataque \\
\hline
\end{tabular}


El modo de interacción de la dotación innata con las influencias ambientales es el factor que genera distinciones cuantitativas en las pautas cognitivas, afectivas y conductuales de la personalidad.

En los individuos con trastornos de la personalidad las creencias nucleares están altamente pronunciadas. Estas personas presentan las mismas conductas repetitivas en muchas más situaciones que los demás. Entonces, los esquemas inadaptados típicos de los trastornos de personalidad son suscitados por muchas o casi todas las situaciones, teniendo un carácter compulsivo y siendo menos fáciles de controlar o modificar que sus equivalentes en otras personas. Beck et al (2005) caracterizan a los esquemas de los trastornos de personalidad como dotados de generalización excesiva, inflexibilidad y resistencia al cambio. Entonces, toda situación que opera sobre sus contenidos, los activa en lugar de activar esquemas más adaptativos.

\section{Procesamiento de la información y perso- nalidad}

El modo como las personas procesan los datos sobre sí mismas y sobre los demás sufre la influencia de sus creencias y los otros componentes de su organización cognitiva (Beck et al, 2005). Cuando existe algún tipo de trastorno, la utilización ordenada de esos datos se vuelve sistemáticamente distorsionada de un modo disfuncional. Esa distorsión de la interpretación y la conducta consecuente reciben su forma de creencias disfuncionales.

Debido a que los datos sensoriales en bruto tienen en sí mismo un limitado valor informativo, es preciso transformarlos en una especie de configuración con sentido. La integración en una pauta coherente es el producto de los esquemas de orden superior que operan sobre los datos sensoriales brutos en un contexto específico, y que adscriben significado a dichos datos mediante esquemas de un nivel más bajo (i.e., esquemas condicionales, de tipo 'si... entonces...').

Además, el procesamiento de la información es influido por un mecanismo de feedforward (Mahoney, 1984). Los esquemas cognitivos operan en diferentes niveles. En el nivel más básico se encuentran aquellos que contienen creencias nucleares, por ejemplo, la creencia 'no merezco se amada'. Luego, esa creencia se manifiesta por la disposición a asignar cierto significado sistemático a todo hecho importante (Beck, 1964, 1967) y toma una forma condicional: 'si los hombres me rechazan, significa que no puedo ser amada'. En general, este tipo de creencias se mantienen a la expectativa cuando la persona no está expuesta a situaciones que la activan. Cuando se produce una situación relacionada con el tema, esa creencia o esquema desplaza a otras más razonables, aunque estas últimas fueran más apropiadas (Beck, 1967). Es por ese mecanismo que en los trastornos de personalidad los esquemas son hipervalentes, porque se activan inhibiendo a los demás esquemas.

Aunque fenómenos tales como pensamientos, sentimientos y deseos se limiten a pasar fugazmente por nuestra conciencia, las estructuras subyacentes responsables de esas experiencias subjetivas son relativamente estables y persistentes. Además, no son en sí mismas conscientes, aunque por medio de la introspección se pueda identificar su contenido. Sin embargo, a través de procesos conscientes tales como el reconocimiento, la evaluación y la puesta a prueba de sus interpretaciones (i.e., técnicas básicas de la terapia cognitiva), las personas pueden modificar la actividad de sus estructuras subyacentes y en algunos casos cambiarlas sustancialmente (Beck et al, 2005).

\section{Características de los esquemas}

El concepto de 'esquema' se ha empleado para designar las estructuras que integran y adscriben significado a los hechos. El contenido de los esquemas puede tener que ver con las relaciones personales (i.e., como las actitudes respecto de uno mismo o los demás) o con categorías impersonales (i.e., como los objetos inanimados). A su vez, estos objetos pueden ser concretos (i.e., una silla) o abstractos (i.e., la libertad).

Los esquemas tienen cualidades estructurales adicionales, como la amplitud (i.e., son reducidos, discretos o amplios), la flexibilidad o rigidez (i.e., capacidad para la modificación) y la densidad (i.e., preeminencia relativa en la 
organización cognitiva). También se los describe en función de su valencia, o sea, su grado de activación en un momento dado. El nivel de activación escila entre los extremos de latente e hipervalente. Cuando son latentes, no participan en el procesamiento de la información, cuando están activados, canalizan el procesamiento cognitivo desde las primeras etapas hasta las finales (Beck et al, 2005).

La Figura 2 resume los conceptos que influyen en la formación de esquemas, y los tipos de esquemas resultantes.

En el campo de la psicopatología, el término 'esquema' se ha aplicado a estructuras con un contenido idiosincrásico altamente personalizado, que se activan durante trastornos tales como la depresión o ansiedad, y se vuelven predominantes. Cuando son hipervalentes, esos esquemas desplazan y probablemente inhiben a otros que podrían ser más adaptativos (Beck, 1964, 1967; Beck et al, 1995). En los trastornos de la personalidad, los esquemas se asemejan a los activados por patologías concernientes al Eje I, pero se diferencian porque forman parte del procesamiento de la información cotidiano.

La personalidad puede concebirse como una organización relativamente estable compuesta por sistemas y modalidades. Los sistemas de estructuras entrelazadas o esquemas son los responsables de la secuencia que va desde la recepción de un estímulo hasta el punto final de una respuesta conductual.
La integración de los estímulos ambientales y la formación de una respuesta adaptativa dependen de esos sistemas de estructuras especializadas. En la memoria, la cognición, el afecto, la motivación la acción y el control, participan sistemas separados, pero relacionados. Las unidades básicas de procesamiento, que son los esquemas, están organizados según sus funciones y su contenido. Diferentes tipos de esquemas tienen disímiles funciones. Cuando ciertos esquemas son hipervalentes, el umbral para la activación de los subesquemas constitutivos es bajo: los pone en marcha con facilidad un estímulo trivial. Son también 'predominantes'; es decir que en el procesamiento de la información desalojan con facilidad a esquemas o configuraciones más apropiados (Beck, 1967).

\section{El papel del afecto en la personalidad}

El afecto está relacionado con el placer y el dolor, y por lo tanto, desempeña un papel clave en la movilización y el mantenimiento de las estrategias cruciales. Las estrategias de supervivencia y reproducción parecen operar en parte a través de su ligazón con los centros de placer-dolor. Las actividades dirigidas a la supervivencia y la reproducción conducen al placer cuando se consuman con éxito, y al dolor cuando se ven frustradas. Otras estructuras emocionales que producen ansiedad y tristeza, respectivamente, refuerzan las señales cognitivas que nos alertan ante el peligro o acentúan la percepción de que hemos perdido algo valioso (Beck et al, 1995).

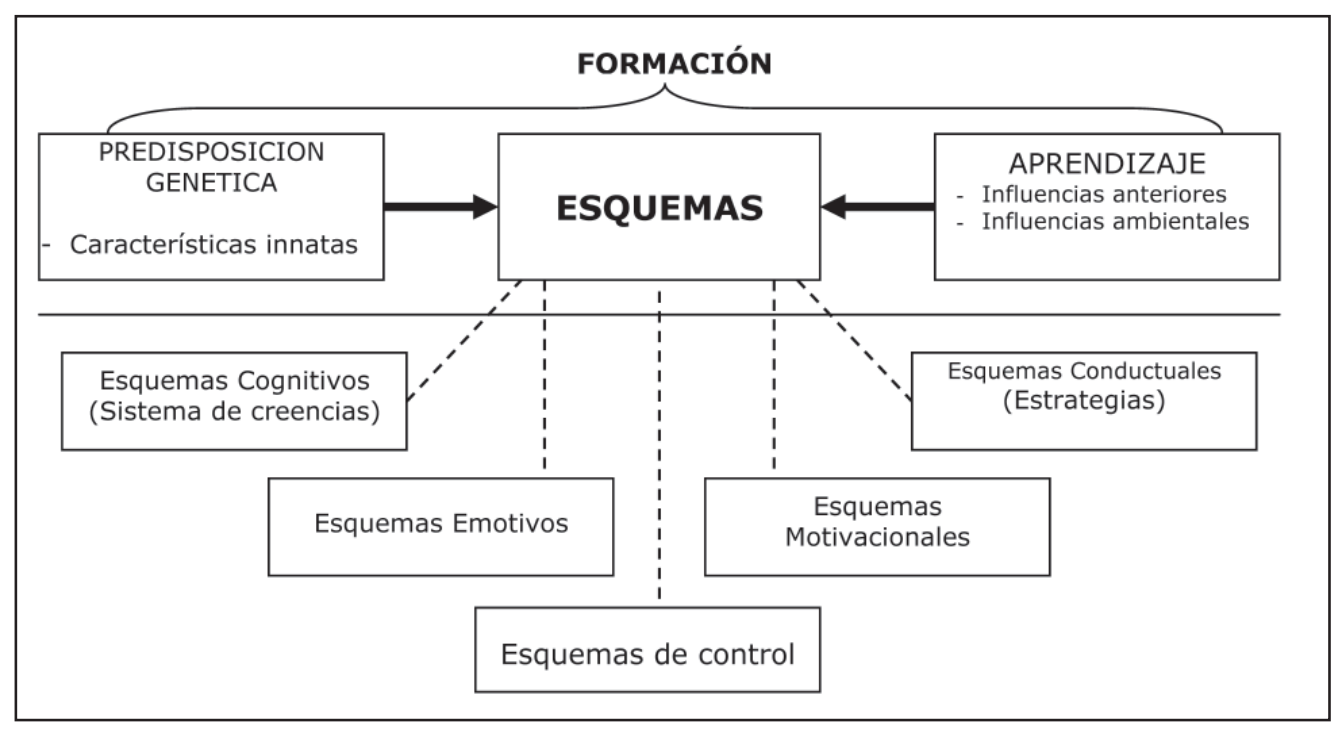

Figura 2. Formación y tipos de esquemas, en base a Beck et al (2005) 
Por lo tanto, los mecanismos emocionales sirven para reforzar conductas dirigidas a la supervivencia y están vinculados a las expectativas y experiencias de diversos tipos de placer. Al mismo tiempo, existen mecanismos complementarios que sirven para desalentar conductas potencialmente peligrosas a través de la activación de ansiedad y disforia (Beck, Emery \& Greenberg, 1985).

\section{Mecanismos automáticos involucrados en la modulación de la conducta}

Entre los componentes básicos de la organización de la personalidad hay secuencias de diferentes tipos de esquemas que actúan como una línea de montaje (Beck et al, 2005). Se puede considerar que esas estructuras operan en una progresión lineal lógica. Por ejemplo, la exposición a estímulos peligrosos activa el correspondiente 'esquema de peligro', que comienza a procesar la información. Luego se activan en secuencia los esquemas afectivos, motivacionales, de acción y de control. La persona interpreta la situación como peligrosa (i.e., mediado por su esquema cognitivo, siente ansiedad -esquema afectivo-, quiere alejarse -esquema motivacional- y se moviliza para huir -esquema de acción-. Si juzga que la huida es contraproducente, puede inhibir ese impulso -esquema de control-). La Figura 3 ejemplifica la pauta operativa descripta.

El sistema interno de control opera en conjunción con el de acción para modular, modificar o inhibir impulsos. Este sistema también se basa en creencias, muchas de las cuales son adaptativas. Mientras los impulsos constituyen los 'quiero', esas creencias constituyen los 'hacer' y 'no hacer' (Beck, 1976).
El sistema de control desempeña un papel crucial en los trastornos de personalidad, y por eso merece especial atención en terapia. Las funciones de control pueden dividirse en las relacionadas con la autorregulación y las involucradas con el ambiente externo. Los procesos autorregulatorios son de especial importancia para los trastornos de personalidad, ya que se relacionan con el modo como las personas se comunican consigo mismas. Las comunicaciones internas consisten en la autoobservación, la autoevaluación y la autopercepción, las advertencias y las instrucciones dirigidas a uno mismo (Beck, 1976). Cuando son exagerados o deficientes, esos procesos se vuelven más visibles. Las personas que se observan demasiado tienden a ser inhibidas, mientras que una inhibición escasa facilita la impulsividad. La autopercepción simplemente representa la observación de sí mismo, la autoevalución implica formular juicios sobre el propio valor: bueno-malo, amable-rechazable.

En el funcionamiento normal, el sistema de control actúa más o menos automáticamente. El individuo puede no percatarse de esas señales de sí mismo a menos que centre específicamente su atención en ellas. Entonces, esas cogniciones pueden representarse en una forma particular denominada pensamientos automáticos (Beck, 1967). A su vez, las autoevaluaciones y autoinstrucciones derivan de estructuras mas profundas: los autoconceptos o autoesquemas. De hecho, los autoconceptos extremadamente negativos (o positivos) pueden ser los factores que llevan a alguien de tener un 'tipo de personalidad', a tener un trastorno en ésta. En el curso de la maduración desarrollamos una mezcla confusa de reglas que proporcionan el sustrato de nuestras evaluaciones y autoinstrucciones.

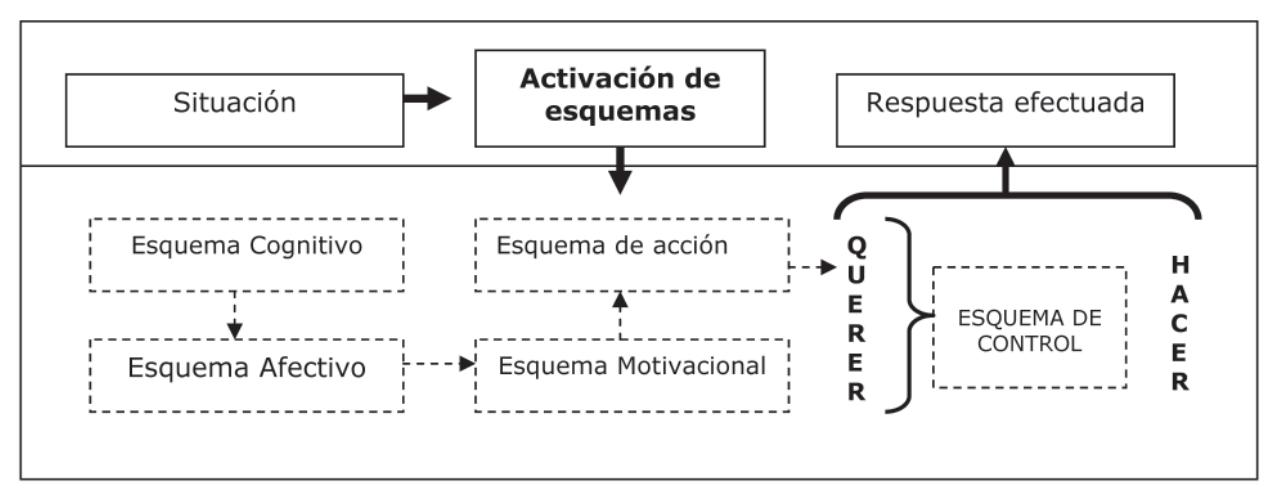

Figura 3. Operación lineal de los esquemas ante una situación determinada, en base a Beck et al (2005) 
Estas reglas constituyen la base para establecer normas, expectativas y planes de acción para nosotros mismos.

\section{El cambio cognitivo en los trastornos de personalidad}

Cuando las personas desarrollan un trastorno del Eje I, tienden a procesar la información de forma selectiva y de manera disfuncional. Las creencias que el paciente mantenía antes de sufrir depresión o ansiedad se convierten en mucho más firmes y dominantes, tornándose extremas y más irrebatibles. Además, como planteamos anteriormente, ciertos aspectos de la imagen negativa con respecto a sí mismo se agudizan y amplían. Los pensamientos negativos que eran pasajeros o menos sólidos antes de la depresión o la ansiedad se convierten en incontestables y se apoderan de los sentimientos y del comportamiento (Beck, 1963). Luego, las creencias condicionales específicas crecen hasta incluir un abanico de situaciones cada vez mayor. Como consecuencia la depresión o ansiedad se agrava y las creencias se vuelven absolutas y nucleares. En la Tabla 2 se esquematiza esta evolución de las creencias.

La facilidad con que los pacientes aceptan sus creencias condicionales durante la depresión o los trastornos por ansiedad sugiere que han perdido temporalmente la capacidad para someter sus interpretaciones disfuncionales a prueba de realidad. La discapacidad cognitiva reposa en la pérdida temporal del acceso a los modos racionales de cognición mediante los cuales ponemos a prueba nuestras conclusiones. La terapia cognitiva apunta explícitamente a 'reactivar' el sistema de prueba de la realidad. Mientras tanto, el terapeuta le sirve al paciente como verificador auxiliar del valor de realidad de estas creencias.
Es que, como ya se señaló, el modo como un individuo utiliza los datos sobre sí mismo y los otros es influido por la organización de su personalidad; $y$, cuando hay una trastorno de algún tipo (i.e., Eje I o II) el procesamiento de esos datos es disfuncional y desordenado. La distorsión de la interpretación y la conducta consecuente es conformada por las creencias y actitudes disfuncionales de los pacientes (Beck et al, 2005).

En la terapia, las creencias que forman la matriz del trastorno de la personalidad son las más difíciles de cambiar. Las creencias asociadas sólo con los trastornos afectivos y por ansiedad son susceptibles de una mejoría más rápida, porque son menos estables. Hay una circulación de la energía, o catexia, de una modalidad a otra.

\section{Estrategias y estilos de pensamiento}

Un trastorno se caracteriza por una constelación de creencias, actitudes, afectos y estrategias -o conductas- específicas. Beck et al (2005) considera que es posible dar un perfil distintivo de cada uno de los trastornos sobre la base de sus rasgos típicos cognitivos, afectivos y conductuales, y presenta una tipología sobre cada trastorno. Claro está que las manifestaciones visibles de cada trastorno son las estrategias típicas de cada uno. A saber, los trastornos de personalidad tienden a presentar pautas de comportamiento infradesarrolladas o hiperdesarrolladas. Sobre cada tipo de estos, ciertas estrategias hiperdesarrolladas pueden derivar o compensar un tipo específico de autoconcepto, y ser una respuesta a particulares experiencias del desarrollo.

Como reflejo de las estrategias conductuales de los pacientes, están los estilos de pensamiento.

Tabla 2. Evolución de creencias: desde una personalidad normal hacia un trastorno de la personalidad., en base a Beck et al (2005)

\begin{tabular}{|l|l|l|}
\hline \multicolumn{1}{|c|}{ Normalidad } & \multicolumn{1}{|c|}{ Trastorno Eje I } & \multicolumn{1}{c|}{ Trastorno Eje II } \\
\hline $\begin{array}{l}\text { Las creencias negativas sobre sí } \\
\text { mismo y los otros son } \\
\text { transitorias y de carácter } \\
\text { condicional. }\end{array}$ & $\begin{array}{l}\text { Las creencias se vuelven más } \\
\text { absolutas y generalizadas, } \\
\text { predominando aún el carácter } \\
\text { condicional. }\end{array}$ & $\begin{array}{l}\text { Las creencias negativas se } \\
\text { vuelven } \\
\text { extremas y rígidas y gobiernan } \\
\text { los sentimientos y la conducta } \\
\text { del paciente. }\end{array}$ \\
\hline $\begin{array}{l}\text { (i.e., si alguien no me guía en } \\
\text { situaciones nuevas, no salgo a } \\
\text { flote) }\end{array}$ & $\begin{array}{l}\text { (i.e., si no tienes éxito, careces } \\
\text { de valor) }\end{array}$ & (i.e.., Carezco de valor) \\
\hline
\end{tabular}


Estos tienen que ver con la manera de procesar la información, en tanto opuesta al contenido específico del procesamiento, y también son característicos para cada trastorno del Eje II.

\section{ESTRATEGIAS DIAGNOSTICAS}

La elección de las estrategias de evaluación depende de varios factores. Un típico enfoque dimensional consiste en cuantificar el grado en el que están presentes, o ausentes, los diferentes trastornos del Eje II. Existen distintos métodos de medida de este enfoque, como ser: sumar el número de criterios que cumple un paciente evaluado con una entrevista estructurada; usar un autoinforme con ítems redactados para evaluar criterios del DSM o ítems que evalúan trastornos específicos en múltiples ámbitos; o usar un autoinforme que estudie un solo ámbito como el de las creencias disfuncionales. Un enfoque dimensional alternativo incluye la evaluación de rasgos de personalidad o constructos del tipo rasgo (e.g., esquemas inadaptados tempranos) relevantes para los trastornos de la personalidad. Los autoinformes son el principal método de medida para este tipo de modelo dimensional.

Por otro lado, un enfoque categórico de evaluación implica clasificar o diagnosticar a los individuos dentro de una determinada clase o categoría, como las establecidas por el DSM, sin importar el grado en que se da el trastorno. Es decir, hay sólo dos opciones: tener un desorden o no tenerlo. Este enfoque ofrece varias ventajas, como la claridad conceptual, la facilidad de explicarlo y la familiaridad que ya le tienen los clínicos. Aquí se incluyen las entrevistas no estructuradas y las estructuradas. Estas últimas incrementan la fiabilidad y precisión de los diagnósticos y ahorran tiempo a clínicos y pacientes.

No obstante, es posible también conjuntar los enfoques dimensionales y categóricos a la hora de diagnosticar. Una entrevista estructurada puede ayudar a tomar decisiones categóricas acerca de la presencia o ausencia de un trastorno de la personalidad. Los autoinformes pueden proporcionar perfiles ideográficos que acaben de dibujar el cuadro clínico del paciente, facilitando la conceptualización cognitiva y la planificación del tratamiento.
Entre los elementos cognitivos claves a considerar cuando se evalúan trastornos de la personalidad se incluyen la visión característica que de tiene de uno mismo y de los demás, las creencias disfuncionales, las estrategias principales y los afectos y los estilos específicos de procesar la información.

A continuación se describirán y ejemplificarán más específicamente cada una de las estrategias de evaluación con las que se cuenta a la hora de diagnosticar patologías de personalidad:

- Autoinformes: Dentro de los instrumentos con los que se cuenta para recoger información relevante sobre los trastornos de la personalidad, constituyen la estrategia más práctica en este sentido. En las últimas décadas, se han desarrollado numerosos cuestionarios, algunos de los cuales fueron diseñados para definir trastornos de personalidad tal y como lo hace el Eje II del DSM. Dos de los más comúnmente usados son el Millon Clinical Multiaxial Inventory (MCMI-III; Millon, Millon \& Davis, 1994) y el Personality Diagnostic Questionnaire Revised (PDQ-R; Hyler \& Rieder, 1987). Otros fueron desarrollados para evaluar rasgos relevantes de los trastornos de personalidad, por ejemplo el DAPP-BQ (Livesley, 1990), el SNAP (Clark, 1993) y el Wisconsin Personality Disorders Inventory (WISPI; Klein, Benjamin, Rosenfeld, Treece, Husted \& Greist, 1993). Asimismo, existen otros cuestionarios construidos específicamente para evaluar dimensiones cognitivas relevantes en los trastornos de personalidad, como ser el Personality Belief Questionnaire (PBQ; Beck \& Beck, 1991) y el Schemma Questionnaire (SQ; Young \& Brown, 1994). En comparación con otras estrategias, los autoinformes requieren menos formación y menos tiempo de administración. A su vez, proporcionan puntuaciones que pueden ser comparadas con grupos normativos y usadas para preparar perfiles. Los cuestionarios mencionados anteriormente tienen en general una buena validez, una muy buena consistencia interna y confiabilidad test-retest y una aceptable validez de constructo.

- Entrevistas clínicas estructuradas: Dentro de las entrevistas clínicas estructuradas más utilizadas e investigadas para evaluar 
trastornos de personalidad y dimensiones de la personalidad relacionadas, se incluyen la Structured Clinical Interview for DSM-IV (SCID-II; First, Spitzer, Gibbon \& Williams, 1995), el Personality Disorder Examination - Revised (PDE-R; Loranger, Susman, Oldham \& Russsakoff, 1987) y la Structured Interview for DSM-IV Personality Disorders (SIDP-R; Pfohl, Blum, Zimmerman \& Stangl, 1989). Estas tres entrevistas han mostrado una alta confiabilidad cuando son administradas por clínicos experimentados. Es por ello que la formación y la competencia del clínico es indispensable. En cuanto al producto final de las mismas, las estimaciones de la confiabilidad han sido más altas para las puntuaciones dimensionales que para los diagnósticos categóricos.

- Uso de informantes: Tanto los autoinformes como las entrevistas clínicas estructuradas dependen de que los pacientes sean capaces y deseen informar adecuadamente sobre sus experiencias internas y sus pautas de conducta a largo plazo. Sin embargo, existen posibles formas de pérdida de autenticidad de los autoinformes. Dicho sesgo puede proceder del efecto del estado psíquico del paciente cuando realiza el informe. Es por ello que resulta muy útil que los clínicos puedan añadir al autoinforme del paciente datos obtenidos a partir de informantes que conozcan bien a éste, como miembros de su familia, amigos y compañeros de trabajo. Dichos informantes pueden proporcionar datos sobre las pautas conductuales que el paciente no percibe o no quiere revelar. Cuando hay discrepancias entre los autoinformes y lo manifestado por los informantes, los clínicos pueden acudir a otras fuentes de información -observación clínica, informes sobre tratamientos pasados, informes de otros especialistas- para aunar criterios.

- Entrevistas clínicas no estructuradas: muchos clínicos utilizan la entrevista no estructurada para evaluar trastornos de la personalidad. Sin embargo, cabe señalar que diversas investigaciones hallaron poco acuerdo entre las entrevistas estructuradas y no estructuradas (Steiner, Tebes, Sledge \& Walker, 1995). La experiencia y sofisticación clínica del entrevistador son imprescindibles para llevar a cabo una evaluación adecuada sin una entrevista estructurada. No obstante, ya sea que se utilice una entrevista estructurada o no estructurada, es esencial determinar no sólo la actual existencia de los rasgos o criterios del trastorno de personalidad sino también la persistencia, su grado de solapamiento con otros y el nivel de incapacidad relacionados con esas características.

\section{Medidas cognitivas de patología de la personalidad}

Es importante destacar que la teoría cognitiva de los trastornos de la personalidad hace hincapié en la importancia de los esquemas y creencias nucleares del paciente como estructuras organizacionales y representaciones mentales globales que guían el proceso de información y la conducta. Es por ello que la terapia cognitiva presta mucha atención a la evaluación de esquemas, creencias y supuestos relacionados. Parte del supuesto que las historias evolutivas de los pacientes, los problemas, síntomas actuales y las conductas durante la entrevista proporcionan claves para revelar sus creencias disfuncionales. A su vez, la relación terapéutica proporciona un importante contexto para evaluar algunas creencias propias de los trastornos de la personalidad. Por tal motivo, se describirán a continuación dos autoinformes que han sido desarrollados con la finalidad de evaluar dichas creencias o esquemas.

- El Personality Belief Questionnaire (Beck \& Beck, 1991): EI PBQ es una prolongación natural de la teoría cognitiva de los trastornos de la personalidad., Beck et al (1990) propusieron una lista de esquemas prototípicos para la mayor parte de los trastornos del Eje II. De este modo, se enumeraron las creencias y supuestos específicos que se piensan están asociadas con cada trastorno. Dicho listado de definiciones de los esquemas fue luego incorporado en el PBQ. Este cuestionario contiene nueve escalas en total que pueden ser administradas juntas o separadas y que corresponden a nueve de los trastornos de personalidad del Eje II del DSM-III-R. Las nueve escalas contienen 14 ítems, lo que resulta en un total de 126 ítems. La consigna del cuestionario es la siguiente: 'Por favor, lea los siguientes enunciados y evalúe en qué medida cree que son ciertos. Intente juzgar cómo se siente la mayor parte del tiempo acerca de cada enunciado'. 
Las opciones de respuesta van de 0: 'No es cierto en absoluto' a 4: 'Es totalmente cierto'. Finalmente es importante destacar las dos formas en que el PBQ puede usarse clínicamente: para proporcionar un perfil cognitivo e identificar creencias disfuncionales que pueden ser atendidas durante el tratamiento.

- El Schema Questionnaire (Young \& Brown, 1994): A diferencia del $P B Q$ que fue diseñado específicamente para el Eje II, el SQ es un ejemplo de enfoque dimensional y de constructo que además es conceptualmente independiente de la nosología del Eje II. Más bien el SQ fue diseñado para medir esquemas inadaptados tempranos -EIT- relacionados de forma cruzada con las categorías DSM. Los EIT pueden definirse como 'ítems muy amplios y generales sobre las relaciones que tenemos con los demás, pero desarrolladas durante la niñez y elaboradas durante toda la vida, siempre disfuncionales, aunque en diferentes grados' (Young, 1994). Son descritos como pautas profundamente enraizadas importantes para el concepto del yo de cada uno. Young identificó 18 esquemas organizados bajo cinco dominios:

\section{Dominio de Desconexión y Rechazo:}

1) Esquema de Abandono/Inestabilidad

2) Esquema de Desconfianza/Abuso

3) Esquema de Privación Emocional

4) Esquema de Defectuosidad/Vergüenza

5) Esquema de Aislamiento Social/ Alienación

2. Dominio de Autonomía y Desempeño Deteriorados:

6) Esquema de Dependencia/Incompetencia

7) Esquema de Vulnerabilidad al Daño o a la Enfermedad

8) Esquema de Entrampamiento Emocional/Yo Inmaduro

9) Esquema de Fracaso

3. Dominio de Límites Insuficientes:

10) Esquema de Derecho/Grandiosidad

11) Esquema de Autocontrol Insuficiente/ Autodisciplina
4. Dominio de Orientación Hacia los Otros:

12) Esquema de Subyugación

13) Esquema de Autosacrificio

14) Esquema de Búsqueda de Aprobación/Búsqueda de Reconocimiento

5. Dominio de Sobrevigilancia e Inhibición:

15) Esquema de Negatividad/Pesimismo

16) Esquema de Inhibición emocional

17) Esquema de Estándares Implacables / Hipercrítica

18) Esquema de Condena

EI SQ es un autoinforme de 205 ítems desarrollado para medir 18 esquemas. Asimismo, se ha desarrollado y probado una versión reducida del SQ. EI Schema Questionnaire - Short Form (SQ-SF) contiene 75 ítems seleccionados de entre los que forman la versión completa para identificar los esquemas inadaptados tempranos. EI SQ es de gran utilidad para obtener perfiles de pacientes. Asimismo, la teoría de los esquemas también da mucha importancia a los estilos de afrontar las cosas y los modos de esquemas (Young, 2002). Según esta teoría, la gente se maneja con sus esquemas de manera diferente en diferentes momentos. Es por ello que Young y sus colegas han propuesto tres estilos desadaptativos hipercompensación, rendición y evitación pudiendo existir en forma leve en poblaciones no clínicas, en formas rígidas y extremas en poblaciones clínicas. Los modos de esquemas son definidos como estados emocionales del momento y respuestas ante situaciones vitales que están activos para un individuo. La activación de un modo disfuncional conduce a emociones fuertes o estilos de afrontamiento rígidos que, entonces, toman el control del funcionamiento de una persona. Esos modos pueden categorizarse de la siguiente manera: modos infantiles (niño vulnerable, niño enfadado, niño impulsivo/indisciplinado y niño feliz), modos de afrontamiento desadaptativo (rendición sumisa, protector desprendido y sobrecompensador), modos desadaptativos de padres (padre punitivo, padre exigente) y modo sano de adulto. Finalmente, hay que destacar que Young plantea que la gente cambia de un modo a otro y que, debido a esos cambios, algunos esquemas que estaban antes en letargo se activan. Siguiendo este criterio, las puntuacio- 
nes SQ o SQ-SF serían bastante inestables. Sin embargo, las investigaciones han develado que estas escalas son estables para las poblaciones clínicas (Wellburn, Coristine, Dagg, Pontefract \& Jordan, 2002).

\section{Consideraciones sobre el proceso de eva- Iuación}

El plan de tratamiento de un caso en particular, se empieza a diseñar sólo después de la evaluación y conceptualización del mismo. A la hora de evaluar patologías de la personalidad no deben pasarse por alto ciertos puntos esenciales:

- La necesidad de tener gran familiaridad con los criterios específicos y generales de los trastornos de personalidad.

- La importancia de prestar la suficiente atención a la hora de evaluar la persistencia y el grado de deterioro del estado del paciente, ya que lo hace con base en ciertos criterios y rasgos específicos, que son correlatos cognitivos de la patología de la personalidad. Es esencial poder diferenciar los estados psiquiátricos episódicos o pasajeros de los rasgos de personalidad permanentes.

- La importancia de la formación y competencia del clínico, ya que al ser los diagnósticos del Eje II más inferenciales que los del Eje I, un clínico inexperto puede fácilmente ver más patología en un paciente de la que verdaderamente hay.

\section{TRATAMIENTO DE LOS TRASTORNOS DE LA PERSONALIDAD}

Existen diferencias en cuanto al tratamiento de aquellos pacientes que presentan síntomas propios de los trastornos del Eje I como aquellos que padecen un trastorno correspondiente al Eje II, aunque en un principio ambos tipos de pacientes presenten síntomas similares. Según Beck et al (2005), aquellos que padecen trastornos correspondientes al Eje I retornan a su modo de pensamiento premórbido una vez que se recuperan de su cuadro sintomático. Pero hay pacientes que aunque la depresión haya cedido siguen manifestando ciertas características que estaban presentes durante la misma. Esto se debe a que las creencias e interpretaciones defectuosas que dan lugar a las conductas desadaptativas en las personas con trastorno de la personalidad se encuentran estructuralizadas, es decir, incorporadas a la estructura cognitiva normal. Por este motivo se hace necesario que tanto el paciente como el terapeuta reconozcan que esas creencias residuales básicas están profundamente arraigadas y no ceden fácilmente con técnicas que se utilizan para los trastornos de ansiedad y depresión. Por ello, para producir un cambio estructural que sea capaz de modificar un trastorno de la personalidad se necesita mucho más tiempo y esfuerzo que para modificar el pensamiento disfuncional de los trastornos afectivos, lo que lleva a que muchas veces sea necesario realizar un proceso largo y tedioso con este tipo de pacientes. Beck et al (2005) plantean como objetivos generales para el tratamiento de los trastornos de la personalidad los siguientes:

1. Conceptualización del caso: el terapeuta debe realizar una conceptualización específica de cada paciente que le permita comprender el comportamiento inadaptado del mismo y modificar las actitudes disfuncionales.

2. Identificación y modificación de los esquemas: el terapeuta debe utilizar los datos que se recogen para poder reconocer los esquemas nucleares y las reglas de pensamiento que rigen las conductas de estos pacientes para que puedan comprender el origen de sus conductas disfuncionales y cómo éstas a su vez refuerzan los esquemas. Esta información servirá para modificar las creencias actuales desadaptativas por otras que sean más funcionales.

3. Especificar las metas que persiguen los pacientes y que subyacen a las aspiraciones y ambiciones que expresan.

4. Énfasis en la relación paciente/terapeuta: construir una relación de trabajo que se caracterice por la cooperación y la confianza para poder llevar a cabo la terapia de manera adecuada. Se debe explorar las reacciones emocionales que manifiesta el paciente ya que las mismas le permitirán comprender el sistema de pensamientos y creencias que da soporte y sentido a esas reacciones. 
Por este motivo resulta importante utilizar el descubrimiento guiado para que el paciente, con la ayuda del terapeuta explore los significados subyacentes a sus experiencias y pueda identificar el motivo de las reacciones exageradas a ciertas situaciones.

Beck et al (2005), plantean que a la hora de planificar y aplicar las técnicas y estrategias específicas para alcanzar los objetivos del tratamiento, como primera medida hay que tener en cuenta no solo la patología del paciente sino sus modos particulares de incorporar y utilizar la información sobre sí mismo ya que los métodos eficaces en un momento y con un paciente determinado pueden ser ineficaces en otro momento y/o con otro tipo de paciente. El tratamiento que proponen estos autores para los trastornos de la personalidad se operacionaliza a través de diversas técnicas como lo son las cognitivas y las conductuales, dentro de las cuales se incluyen también la evocación de las experiencias de la niñez y el empleo de evocación de imágenes que resultan eficaces para estos trastornos. Si bien existe una división arbitraria de las técnicas cognitivas y conductuales estos autores sostienen que ninguna técnica en sí es puramente cognitiva o conductual ya que las estrategias cognitivas pueden producir cambios conductuales y viceversa, y ambas resultan complementarias en el tratamiento de los trastornos de personalidad.

\section{Estrategias y Técnicas Cognitivas}

Beck y sus colaboradores sostienen que las mismas técnicas que se emplean para evaluar los pensamientos automáticos de los trastornos correspondientes al Eje I, sirven también para tratar los trastornos de personalidad (Beck et al, 1985; Beck, Rush, Shaw \& Emery, 1979). Algunas de las técnicas cognitivas para tratar estos trastornos son:

- Sondeos cognitivos: tiene como objetivo que el paciente, junto con la ayuda del terapeuta, identifique las situaciones que padece y que le generan malestar, pero centrándose en las bases cognitivas de las mismas. Este sondeo puede realizarse mediante la técnica de la flecha hacia abajo (Beck et al, 1985) que consiste en explorar los significados de los pensamientos más superficiales hasta llegar a las más profundas (i.e., esquemas nucleares) para tratar de modificarlas mediante un razonamiento realista y lógico.

- Abordar los esquemas: su objetivo es que el paciente, con la ayuda del terapeuta pueda identificar las reglas que rigen sus conductas disfuncionales para después trabajar en su modificación de manera tal que permita establecer un funcionamiento más adaptativo (Beck et al, 2005). Al trabajar con los esquemas del paciente el terapeuta puede tener varias opciones de trabajo:

1. Reestructuración esquemática: consiste en atenuar los esquemas disfuncionales para poder desarrollar otros que sean más adaptativos. Esto puede lograrse mediante la técnica de los "diarios de esquema", que tiene como objetivo establecer nuevos esquemas funcionales y poder mantenerlos a través del procesamiento de nuevas situaciones y reformulaciones de situaciones anteriores. El paciente podría, por ejemplo, dividir en secciones (i.e., trabajo, vida social, en soledad, etc.) y registrar diariamente en cada una ejemplos de aptitud. Esto lo ayuda a contrarrestar su creencia absoluta en los esquemas negativos en momentos de estrés. Otra forma de aplicar esta técnica consiste en que el paciente prevea qué puede ocurrir en una determinada situación si actuara en base a sus esquemas negativos, para después escribir lo que sucedió realmente y hacer una comparación. Una tercera forma de aplicar esta técnica consiste en que el paciente, una vez que empieza a creer en sus esquemas más adaptativos, evalúe las situaciones de la semana en bases a sus esquemas viejos y los nuevos para ver las diferencias y beneficios que encuentra en estos últimos.

2. Modificación esquemática: hace referencia a lograr cambios, más atenuados que en el caso de la reestructuración, en la manera básica de responder al mundo

3. Reinterpretación de los esquemas: supone ayudar al paciente a que comprenda y reinterprete su estilo de vida y sus esquemas de manera más adaptativa.

- Toma de decisiones: cuando los pacientes con trastorno de la personalidad tienen problemas en la toma de decisiones, el terapeuta 
debe entrar en la vida del paciente y actuar de manera colaborativa para que este pueda ir aprendiendo a tomar ciertas decisiones importantes que ayuden a modificar los estilos de personalidad. Una técnica consistiría en que el paciente y el terapeuta definan el problema, a partir del cual establecerán posibles metas y luego realizar un Brainstorming para generar distintas alternativas y proceder a la elección de la más adecuada (D'Zurilla \& Goldfried, 1971). Otra técnica podría ser elaborar una lista de ventajas y desventajas de cada alternativa y asignarle un valor numérico relativo para después elegir el que más adecuado resulte al paciente.

- Descubrimiento guiado: le permite al paciente reconocer las pautas de interpretacion disfuncinales estereotipadas.

\section{- Búsqueda del significado idiosincrásico}

- Rotulación de las inferencias: para que el paciente tome conciencia del carácter distorsionado de ciertas pautas automáticas de pensamiento.

- Empirismo cooperativo: trabajo con el paciente para poner a prueba la validez de sus creencias, interpretaciones y expectativas.

- Examen de las explicaciones de la conducta de otras personas.

- Ordenamiento en escalas: traducción de las interpretaciones a expresiones graduales para contrarrestar el típico pensamiento dicotómico.

- Reatribución: reasignación de la responsabilidad por acciones y resultados.

- Exageración deliberada: lleva una idea a su extremo, lo que realza las situaciones y facilita la reevaluación de una conclusión disfuncional.

- Examen de las ventajas y desventajas de conservar o cambiar creencias o conductas y la clarificación de los beneficios secundarios.

- Descatastrofización: permitirle al paciente reconocer y contrarrestar la tendencia a pensar exclusivamente en términos del peor desenlace posible de una situación.

\section{Técnicas Conductuales}

Estas técnicas apuntan a tres metas comunes. En primer lugar, a veces el terapeuta necesita trabajar directamente para modificar las conductas autodestructivas. Segundo, si el paciente posee una capacidad deficiente, la terapia debe incluir un componente de construcción de la capacidad. Finalmente, se pueden plantear al paciente distintas tareas para que realice en su casa a fin de que practique y siga poniendo a prueba sus cogniciones disfuncionales (Beck et al, 2005). Entre las técnicas conductuales útiles se encuentran las siguientes:

- Observación y programación de la actividad: permite la identificación retrospectiva y la programación prospectiva de los cambios.

- Programación de actividades de dominio y placer: para realzar la eficacia personal y validar el éxito con las experiencias modificadas y el placer derivado de ello.

- Ensayo de conductas, modelado, entrenamiento en asertividad y la dramatización: para desarrollar habilidades ante los primeros esfuerzos tendientes a responder con más eficacia en situaciones problemáticas antiguas o nuevas.

- Entrenamiento en relajación y distracción conductual: se utilizan cuando la ansiedad se convierte en una amenaza cuando el paciente intenta el cambio.

- Exposición in vivo: en la que se acompaña al cliente a un escenario problemático y le ayuda a abordar esquemas y acciones disfuncionales que no se pudieron tratar en el consultorio.

- Encargos graduales de tareas para que el paciente experimente lo cambios de a poco.

- Con respecto a las técnicas de evocación de las experiencias de la niñez y el empleo de evocación de imágenes, estas tienen como objetivo que el paciente, con ayuda del terapeuta, pueda recrear situaciones traumáticas de su pasado como también las del presente, para activar la interacción defectuosa junto con el afecto y de esta manera reestructurar la experiencia y las actitudes que derivan de estas. 
Esto permite que el paciente no solo logre un insight intelectual sino también emocional para comprender las razones de su autoimagen negativa y poder modificar esa imagen (Beck et al, 2005). Las técnicas experimentales o dramáticas consisten en:

1. Evocación de las experiencias de la niñez: esta técnica resulta esencial en los trastornos de personalidad ya que al recuperar este tipo de material se puede vislumbrar los orígenes de las pautas inadaptadas. La dramatización de situaciones patógenas del pasado permite que el paciente pueda comprender la conducta "mala" de sus padres y poder sentir compasión por ellos, como también entender que su autoconcepto no se basa en la lógica sino que es producto de las reacciones no razonadas de sus padres.

2. Empleo de evocación de imágenes: se emplean imágenes de una determinada situación, lo más detalladamente posible, que permita recrear las interacciones de aquel momento y poder producirse la reestructuración cognitiva.

\section{Plan de tratamiento}

Si bien lo anteriormente expuesto hace referencia a distintas cuestiones inherentes a los trastornos de personalidad, no debe pasarse por alto que cada trastorno se caracteriza por una constelación propia de creencias, actitudes, afectos y estrategias o conductas específicas. Por ello, Beck et al (2005) consideran que es posible dar un perfil distintivo de cada uno de los trastornos sobre la base de sus rasgos típicos cognitivos, afectivos y conductuales. Resulta de gran importancia tener en cuenta la tipología formulada por los autores sobre cada trastorno y, a su vez, realizar una adecuada conceptualización de cada caso en particular, identificando los componentes que hacen al perfil cognitivo.
En este trabajo incluimos, en forma de guías esquematizadas para profesionales para facilitar su comprensión, la información básica a considerar para conceptualizar casos. Se exponen detalladamente las características cognitivas, el concepto de sí mismo y de los demás, las principales creencias en sus distintos niveles de operación -nucleares, condicionales e instrumentales o de autoinstrucción-, así como las estrategias más utilizadas en consecuencia. Estas guías fueron realizadas en una carilla cada una con la idea que los psicoterapeutas las tengan a la vista durante las sesiones y que de esta manera puedan conceptualizar sus casos y guiar más fácilmente sus intervenciones. Atento a estas cuestiones en este artículo presentaremos los conceptos centrales que deben guiar la praxis desde el modelo Beck, Freeman, Davis y otros (2005).

A la hora de planificar el curso de tratamiento, resultará fundamental tener en cuenta lo anteriormente expuesto. Por tal motivo también presentamos, en la segunda parte de las guías para cada uno de los trastornos de la personalidad, los objetivos terapéuticos más adecuados y aquellas técnicas más pertinentes en respuesta a los mismos, en vistas a un efectivo abordaje de cada trastorno. Están hechas en una carilla con la intención de facilitarle, en tiempo presente, al clínico la posibilidad de seguir un plan de tratamiento adecuado al caso en particular.

Finalmente, es importante destacar que, más allá de las diferencias que existan entre los distintos abordajes de cada trastorno, siempre existirá como objetivo común y primordial, la construcción de una relación terapéutica basada en la cooperación. Para ello, será necesario lograr un alto grado de acuerdo entre las expectativas del paciente y las del terapeuta acerca de las metas y objetivos terapéuticos, así como enfocar las estrategias de modo tripartito, atendiendo las áreas cognitiva, conductual y afectiva. 


\title{
Guías esquematizadas para profesionales basadas en el modelo de Beck, Freeman, Davis y otros (2005) para cada uno de los trastornos de la personalidad
}

\author{
Trastorno Paranoide de la Personalidad, en base a Pretzer (2005).
}

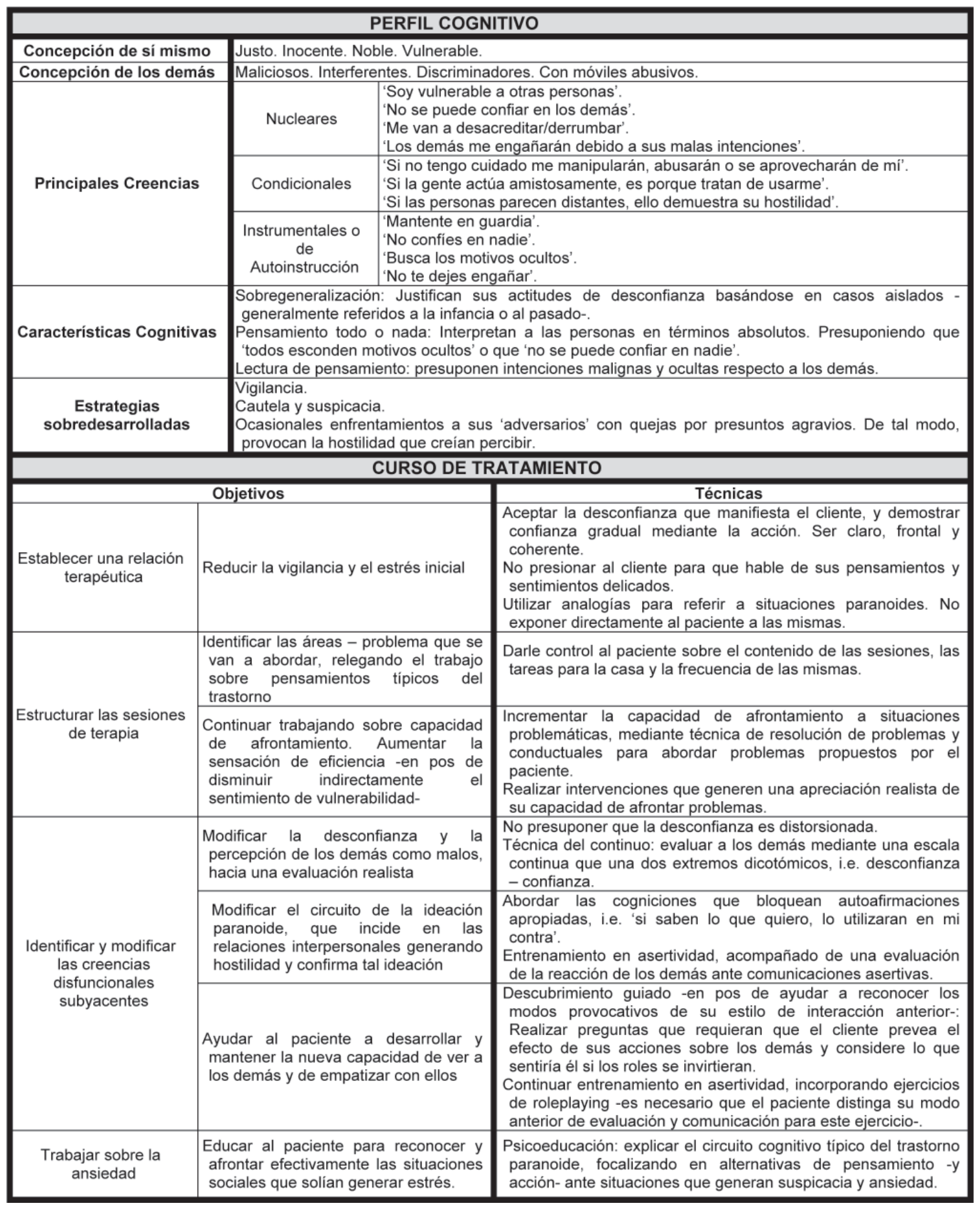


Trastorno Esquizoide de la Personalidad, en base a Morrison y Renton (2005).

\begin{tabular}{|c|c|c|}
\hline \multicolumn{3}{|c|}{ PERFIL COGNITIVO } \\
\hline $\begin{array}{c}\text { Concepción de sí } \\
\text { mismo }\end{array}$ & \multicolumn{2}{|c|}{ Autosuficientes. Solitarios. Independientes. Vulnerables al control ajeno. } \\
\hline $\begin{array}{l}\text { Concepción de los } \\
\text { demás }\end{array}$ & \multicolumn{2}{|l|}{ Intrusivos. Controladores. } \\
\hline \multirow{3}{*}{ Principales Creencias } & Nucleares & $\begin{array}{l}\text { 'Estoy solo'. } \\
\text { 'Las relaciones estrechas con otras personas son desastrosas'. } \\
\text { 'Puedo hacer mejor las cosas solo, sin el estorbo de los demás'. } \\
\text { 'Las relaciones estrechas son indeseables porque interfieren mi } \\
\text { libertad de acción'. }\end{array}$ \\
\hline & Condicionales & $\begin{array}{l}\text { 'Si me acerco demasiado a los demás, me succionarán' } \\
\text { 'No puedo ser feliz a menos que tenga una movilidad total'. }\end{array}$ \\
\hline & $\begin{array}{l}\text { Instrumentales o de } \\
\text { Autoinstrucción }\end{array}$ & $\begin{array}{l}\text { 'No te acerques demasiado'. } \\
\text { 'Mantén las distancias'. } \\
\text { 'No te comprometas'. }\end{array}$ \\
\hline $\begin{array}{l}\text { Características } \\
\text { Cognitivas }\end{array}$ & \multicolumn{2}{|c|}{$\begin{array}{l}\text { Generalización: descalifican a todas las relaciones sociales. } \\
\text { Minimización: Subestiman a las maneras de ser de los demás. } \\
\text { Abstracción selectiva: Se centran en aspectos personales negativos que confirman su creencia } \\
\text { sobre las relaciones sociales. }\end{array}$} \\
\hline $\begin{array}{l}\text { Estrategias } \\
\text { sobredesarrolladas }\end{array}$ & \multicolumn{2}{|c|}{$\begin{array}{l}\text { Mantenerse a distancia, mientras sea posible. } \\
\text { Unirse a los demás solamente por razones específicas u obligaciones, de manera temporal y sin } \\
\text { comprometerse con ellos. }\end{array}$} \\
\hline \multicolumn{3}{|c|}{ CURSO DE TRATAMIENTO } \\
\hline \multicolumn{2}{|r|}{ Objetivos } & Técnicas \\
\hline \multirow{2}{*}{$\begin{array}{l}\text { Establecer una } \\
\text { relación terapéutica }\end{array}$} & $\begin{array}{l}\text { Lograr que el paciente se sienta } \\
\text { cómodo en la terapia }\end{array}$ & $\begin{array}{l}\text { Examinar abiertamente las ventajas y desventajas de la terapia. } \\
\text { Luego de la primera sesión, se puede impartir como tarea para la } \\
\text { casa que realice un cuadro al respecto. } \\
\text { No forzar respuestas afectivas. }\end{array}$ \\
\hline & $\begin{array}{l}\text { Cuidar las reacciones propias } \\
\text { respecto a las creencias del } \\
\text { cliente }\end{array}$ & $\begin{array}{l}\text { Trabajar y controlar las propias reacciones afectivas frente a las } \\
\text { creencias del paciente en contra de las relaciones íntimas, para } \\
\text { que la terapia proceda de manera colaborativa. }\end{array}$ \\
\hline \multirow{2}{*}{$\begin{array}{l}\text { Estructurar las } \\
\text { sesiones de terapia }\end{array}$} & $\begin{array}{l}\text { Identificar las áreas - problema } \\
\text { que se van a abordar }\end{array}$ & $\begin{array}{l}\text { Negociar una lista de problemas y de objetivos en colaboración } \\
\text { mutua, sugestionando comenzar por problemas de ansiedad. } \\
\text { Elicitar información de manera socrática y colaborativa. } \\
\text { No especular ni establecer unilateralmente los objetivos. Ser } \\
\text { pacientes a las iniciativas del cliente. }\end{array}$ \\
\hline & $\begin{array}{l}\text { Comenzar el trabajo con los } \\
\text { problemas que se hayan } \\
\text { acordado }\end{array}$ & $\begin{array}{l}\text { Debido a que usualmente no priorizan problemas cognitivos típicos } \\
\text { del trastorno, es importante comenzar a examinar las creencias } \\
\text { subyacentes a medida que se trabaja con los problemas } \\
\text { acordados. } \\
\text { Profundizar mediante el diálogo socrático las situaciones que al } \\
\text { paciente le generan ansiedad. }\end{array}$ \\
\hline \multirow{3}{*}{$\begin{array}{l}\text { Identificar y modificar } \\
\text { las creencias } \\
\text { disfuncionales } \\
\text { subyacentes }\end{array}$} & $\begin{array}{l}\text { Identificar las situaciones donde } \\
\text { el paciente restringe su afecto }\end{array}$ & $\begin{array}{l}\text { Examinar la conducta autoprotectiva del paciente. } \\
\text { Ayudar al paciente a elaborar una lista de situaciones donde siente } \\
\text { ansiedad y se ensimisma consecuentemente. } \\
\text { Realizar experimentos conductuales, para modificar la respuesta e } \\
\text { identificar la creencia 'escondiendo mis emociones estoy a salvo'. }\end{array}$ \\
\hline & $\begin{array}{l}\text { Reencuadre de creencias } \\
\text { nucleares } \\
\text {-tener en cuenta que es probable } \\
\text { que el paciente las reconozca, } \\
\text { pero que no mida su efecto } \\
\text { perjudicial- }\end{array}$ & $\begin{array}{l}\text { Desafiar las creencias típicas del trastorno en la sesión, mediante } \\
\text { el diálogo socrático -nunca confrontar directamente-. } \\
\text { Dar tareas para la casa que pongan a prueba los efectos de las } \\
\text { creencias. } \\
\text { Explicar el modelo cognitivo, mediante psicoeducación, en pos de } \\
\text { que el paciente relacione sus creencias con sus emociones y } \\
\text { conductas. } \\
\text { Realizar registro de pensamiento y búsqueda de alternativas. }\end{array}$ \\
\hline & $\begin{array}{l}\text { Identificar las dificultades que } \\
\text { pueden surgir en la realización de } \\
\text { tareas }\end{array}$ & $\begin{array}{l}\text { Incluir una columna de dificultades en el registro de pensamientos } \\
\text { automáticos. } \\
\text { Experimentos conductuales para poner a prueba esas creencias y } \\
\text { reemplazarlas por otras creencias más funcionales. }\end{array}$ \\
\hline $\begin{array}{l}\text { Trabajar sobre las } \\
\text { relaciones sociales }\end{array}$ & $\begin{array}{l}\text { Identificar y trabajar sobre } \\
\text { objetivos sociales del paciente - } \\
\text { formación de amistades, } \\
\text { relaciones íntimas, etc.- }\end{array}$ & $\begin{array}{l}\text { Realizar una lista con situaciones sociales que el paciente desee } \\
\text { cambiar. } \\
\text { Planear tareas graduales para conseguir dichas situaciones, } \\
\text { previendo la posibilidad de que no todas sean exitosas. }\end{array}$ \\
\hline
\end{tabular}


Trastorno Esquizotípico de la Personalidad, en base a Morrison y Renton (2005).

\begin{tabular}{|c|c|c|}
\hline \multicolumn{3}{|c|}{ PERFIL COGNITIVO } \\
\hline \multirow{2}{*}{$\begin{array}{l}\text { Concepción de sí } \\
\text { mismo } \\
\text { Concepción de los } \\
\text { demás }\end{array}$} & \multicolumn{2}{|c|}{ Carentes de valor. Anormales. Diferentes } \\
\hline & \multicolumn{2}{|l|}{ Crueles. Peligrosos. Hostiles } \\
\hline \multirow{3}{*}{ Principales Creencias } & Nucleares & $\begin{array}{l}\text { 'Soy especial'. } \\
\text { 'No soy interesante'. } \\
\text { 'La gente es cruel y peligrosa, no me puedo fiar de ellos'. }\end{array}$ \\
\hline & Condicionales & $\begin{array}{l}\text { 'Si intento acercarme a los demás, me rechazarán'. } \\
\text { 'Si soy muy diferente, la gente reparará en mí'. } \\
\text { 'Si tengo experiencias inusuales, entonces puedo ser importante'. } \\
\text { 'Si la gente nota lo raro que soy, se fijarán en mi'. }\end{array}$ \\
\hline & $\begin{array}{l}\text { Instrumentales o de } \\
\text { Autoinstrucción }\end{array}$ & $\begin{array}{l}\text { Evita las situaciones sociales } \\
\text { Mantente solo, en busca de situaciones especiales. }\end{array}$ \\
\hline $\begin{array}{l}\text { Características } \\
\text { Cognitivas }\end{array}$ & \multicolumn{2}{|c|}{$\begin{array}{l}\text { Creencias inusuales: pensamiento mágico, sospechas exageradas e ideas de referencia. } \\
\text { Alucinaciones. } \\
\text { Pensamiento paranoide. }\end{array}$} \\
\hline $\begin{array}{l}\text { Estrategias } \\
\text { sobredesarrolladas }\end{array}$ & \multicolumn{2}{|c|}{$\begin{array}{l}\text { Mantenerse a distancia. } \\
\text { Hipervigilancia. } \\
\text { Reflexión solitaria y usualmente de alto contenido emocional. }\end{array}$} \\
\hline \multicolumn{3}{|c|}{ CURSO DE TRATAMIENTO } \\
\hline \multicolumn{2}{|r|}{ Objetivos } & Técnicas \\
\hline \multirow{2}{*}{$\begin{array}{l}\text { Establecer una } \\
\text { relación terapéutica }\end{array}$} & $\begin{array}{l}\text { Evaluar el nivel de ansiedad } \\
\text { social y falta de confianza en el } \\
\text { terapeuta }\end{array}$ & $\begin{array}{l}\text { Examinar abiertamente las ventajas y desventajas de la terapia. Luego } \\
\text { de la primera sesión, se puede impartir como tarea para la casa que } \\
\text { realice un cuadro al respecto. } \\
\text { Realizar una lista de dos columnas sobre la evidencia de la afirmación } \\
\text { 'no puedo confiar en mi terapeuta' y sobre la evidencia de lo contrario. }\end{array}$ \\
\hline & \begin{tabular}{lr} 
Identificar la existencia de \\
ambivalencia & \multicolumn{1}{c}{ hacia algunos } \\
síntomas (i.e. la visión positiva de \\
experiencias \\
inusuales)
\end{tabular} & $\begin{array}{l}\text { Sopesar ventajas y desventajas de la visión positiva de los síntomas: } \\
\text { Revisar el desarrollo de esas creencias y las situaciones donde fueron } \\
\text { útiles. } \\
\text { Explorar mediante un enfoque cognitivo si existen mejores alternativas } \\
\text { de acción. }\end{array}$ \\
\hline \multirow{2}{*}{$\begin{array}{l}\text { Estructurar las } \\
\text { sesiones de terapia }\end{array}$} & $\begin{array}{l}\text { Identificar las áreas - problema } \\
\text { que se van a abordar }\end{array}$ & $\begin{array}{l}\text { Negociar una lista de problemas y de objetivos en colaboración mutua. } \\
\text { Dedicar tiempo hasta lograr objetivos realistas, asequibles, especificos } \\
\text { y medibles. }\end{array}$ \\
\hline & 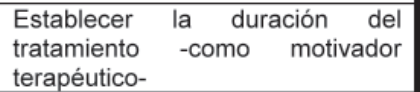 & $\begin{array}{l}\text { Pautar un contrato con un límite temporal de sesiones, con posibilidad } \\
\text { de continuidad, de acuerdo a una evaluación futura de resultados. }\end{array}$ \\
\hline \multirow{3}{*}{$\begin{array}{l}\text { Identificar y modificar } \\
\text { las creencias } \\
\text { disfuncionales } \\
\text { subyacentes }\end{array}$} & $\begin{array}{l}\text { Identificar las situaciones donde el } \\
\text { paciente siente ansiedad / } \\
\text { depresión }\end{array}$ & $\begin{array}{l}\text { Examinar la conducta autoprotectiva del paciente. } \\
\text { Ayudar al paciente a elaborar una lista de situaciones donde siente } \\
\text { ansiedad -o depresión-. } \\
\text { Realizar experimentos conductuales, para modificar la respuesta e } \\
\text { identificar las creencias subyacentes. }\end{array}$ \\
\hline & $\begin{array}{l}\text { Examinar y modificar } \\
\text { creencias paranoides }\end{array}$ & $\begin{array}{l}\text { Revisar la historia de las creencias paranoides, y paralelamente evaluar } \\
\text { las ventajas y desventajas que han tenido. Descubrimiento guiado. } \\
\text { Comprobar mediante ejercicios imaginados la posible utilidad de estas } \\
\text { creencias en determinadas situaciones. } \\
\text { Realizar experimentos conductuales: Modificación de estrategias } \\
\text { protectoras (i.e. evitación social, vestir de manera llamativa que atrae } \\
\text { atención y posibles críticas, ocultar emociones negativas). Es } \\
\text { importante planear con tiempo los experimentos, considerando } \\
\text { proactivamente los posibles problemas. }\end{array}$ \\
\hline & $\begin{array}{l}\text { Reencuadre de creencias } \\
\text { nucleares }\end{array}$ & $\begin{array}{l}\text { Técnicas de cambio de esquemas: examen histórico de las creencias, } \\
\text { descubrimiento guiado, registro de datos empiricos, y búsqueda de } \\
\text { creencias alternativas. }\end{array}$ \\
\hline $\begin{array}{l}\text { Trabajar sobre las } \\
\text { experiencias } \\
\text { perceptivas } \\
\text { inusuales. }\end{array}$ & $\begin{array}{l}\text { Ayudar al paciente a comprender } \\
\text { y modificar el fenómeno de las } \\
\text { alucinaciones }\end{array}$ & $\begin{array}{l}\text { Evaluar creencias sobre fusión de pensamiento y acción, y creencias } \\
\text { metacognitivas sobre protección y seguridad. } \\
\text { Realizar ejercicios de detención de pensamiento o de conductas } \\
\text { alternativas en situaciones que usualmente se acompañan de } \\
\text { alucinaciones. } \\
\text { Confeccionar un registro temporal de situaciones de alucinación, para } \\
\text { evaluar la disminución de las mismas. }\end{array}$ \\
\hline $\begin{array}{l}\text { Trabajar sobre el } \\
\text { estigma asociado a } \\
\text { la etiqueta } \\
\text { diagnóstica }\end{array}$ & $\begin{array}{l}\text { Ayudar al paciente a reducir la } \\
\text { visión de sí mismo como anormal }\end{array}$ & $\begin{array}{l}\text { Normalizar las experiencias del paciente mediante la búsqueda de } \\
\text { información relacionadas al continuo de los rasgos de la personalidad, a } \\
\text { la prevalencia de experiencias alucinatorias y paranoides en la } \\
\text { población general, a la relación entre el uso de drogas y la personalidad } \\
\text { esquizoide y a la naturaleza potencialmente útil de algunas experiencias } \\
\text { inusuales. } \\
\text { Trabajar lo incorporado en sesión con psicoeducación, focalizando en la } \\
\text { diferencia entre estilos de acción y pensamiento, y personalidad } \\
\text { defectuosa. }\end{array}$ \\
\hline
\end{tabular}


Trastorno Antisocial de la Personalidad, en base a Freeman y Davis (2005).

\begin{tabular}{|c|c|c|}
\hline \multicolumn{3}{|r|}{ PERFIL COGNITIVO } \\
\hline $\begin{array}{l}\text { Concepción de sí } \\
\text { mismo }\end{array}$ & \multicolumn{2}{|c|}{ Solitario. Autónomo. Fuertes. Inteligente. Persistente. Obligado por las circunstancias. } \\
\hline $\begin{array}{l}\text { Concepción de los } \\
\text { demás }\end{array}$ & \multicolumn{2}{|c|}{ Débiles. Vulnerables. Explotadores. } \\
\hline \multirow{3}{*}{ Principales Creencias } & Nucleares & $\begin{array}{l}\text { 'Tengo que cuidar de mí mismo'. 'Debo ser el agresor, o seré la víctima'. 'Los } \\
\text { demás son tontos'. 'Son unos explotadores, y por lo tanto tengo derecho a } \\
\text { explotarlos'. 'Soy mejor que los demás'. }\end{array}$ \\
\hline & Condicionales & $\begin{array}{l}\text { 'Si no presiono -o manipulo, exploto, ataco- a los demás, nunca obtendré lo } \\
\text { que merezco'. }\end{array}$ \\
\hline & $\begin{array}{l}\text { Instrumentales o } \\
\text { de Autoinstrucción }\end{array}$ & $\begin{array}{l}\text { 'Pegar primero'. 'Ahora te toca a ti'. } \\
\text { 'Tómalo, te lo mereces'. }\end{array}$ \\
\hline $\begin{array}{l}\text { Características } \\
\text { Cognitivas }\end{array}$ & \multicolumn{2}{|c|}{ Pensamiento lineal, concreto e inmediato. Sistema de valoraciones y atribuciones autoprotectivas. } \\
\hline $\begin{array}{c}\text { Estrategias } \\
\text { sobredesarrolladas }\end{array}$ & \multicolumn{2}{|c|}{$\begin{array}{l}\text { Ataca, defrauda y roba abiertamente. Engaña, explota y estafa mediante manipulaciones astutas y } \\
\text { sutiles. }\end{array}$} \\
\hline \multicolumn{3}{|r|}{ CURSO DE TRATAMIENTO } \\
\hline \multicolumn{2}{|c|}{ Objetivos } & Técnicas \\
\hline \multirow{3}{*}{$\begin{array}{l}\text { Aumentar la } \\
\text { colaboración inicial }\end{array}$} & $\begin{array}{l}\text { Formular un plan } \\
\text { diagnóstico }\end{array}$ & $\begin{array}{l}\text { Informar explícitamente al paciente acerca de su diagnóstico y establecer } \\
\text { condiciones claras para el tratamiento. } \\
\text { Subrayar los límites y la conducta que se espera del paciente y del terapeuta. }\end{array}$ \\
\hline & $\begin{array}{l}\text { Estructurar el } \\
\text { tratamiento de } \\
\text { manera }\end{array}$ & $\begin{array}{l}\text { Establecer un contrato terapéutico que delimite una duración fija de las sesiones, } \\
\text { una politica de cancelaciones determinada, reglas acerca de los contactos entre } \\
\text { sesiones, los requerimientos de los deberes para casa, y el uso apropiado de un } \\
\text { número de teléfono de emergencia. A su vez, debe incluir un número } \\
\text { determinado de sesiones, el cambio conductual esperado y los objetivos } \\
\text { mutuamente aceptados. }\end{array}$ \\
\hline & $\begin{array}{c}\text { Prestar } \\
\text { colaboración por } \\
\text { parte del terapeuta }\end{array}$ & $\begin{array}{l}\text { Estar debidamente formado en el tratamiento de problemas de ira, disociación, } \\
\text { deshonestidad y dificultades relacionales. Tener paciencia, perseverancia, } \\
\text { empatía y la habilidad de no tomarse las reacciones del paciente de manera } \\
\text { personal. } \\
\text { Controlar las respuestas frente a las verbalizaciones y conductas hostiles del } \\
\text { paciente, evitando volverse peyorativo e inflexible. }\end{array}$ \\
\hline \multirow[b]{2}{*}{$\begin{array}{l}\text { Trabajar centrándose en } \\
\quad \text { los problemas }\end{array}$} & $\begin{array}{l}\text { Evitar la negación } \\
\text { de los problemas }\end{array}$ & $\begin{array}{l}\text { Revisar junto al paciente los criterios para el diagnóstico de TAP, comparándolos } \\
\text { con su historia personal. Realizar psicoeducación acerca del trastorno y sus } \\
\text { consecuencias negativas. }\end{array}$ \\
\hline & $\begin{array}{l}\text { Explorar con el } \\
\text { paciente sus } \\
\text { tácticas } \\
\text { distractoras o } \\
\text { controladoras }\end{array}$ & $\begin{array}{l}\text { Explicar al paciente la necesidad de establecer y mantener una estructura en el } \\
\text { trabajo terapéutico -estructura que permite al paciente ser colaborativo, } \\
\text { mejorando así la alianza terapéutica-. Asimismo, los deberes o tareas para hacer } \\
\text { en casa y el auto-monitoraje son vías para que el clienta establezca cierto grado } \\
\text { de estructura fuera de la sesión. }\end{array}$ \\
\hline \multicolumn{2}{|c|}{$\begin{array}{l}\text { Identificar los pensamientos distorsionados } \\
\text { asociados a conductas desadaptativas }\end{array}$} & $\begin{array}{l}\text { Identificar el conjunto de creencias que le convienen al paciente y lo guian en su } \\
\text { conducta, las cuales suelen ser: } \\
\text { 'Mis acciones se justifican porque quiero algo o quiero evitar algo'. 'Mis } \\
\text { pensamientos y sentimientos son totalmente exactos, simplemente porque se me } \\
\text { han ocurrido'. 'Siempre elijo bien'. 'Sé que tengo razón porque siento que está } \\
\text { bien lo que hice'. 'Lo que piensen los otros no tiene por qué pesar en mis } \\
\text { decisiones, a menos que controlen las consecuencias inmediatas para mi'. 'No } \\
\text { habrá consecuencias indeseables, o no me importarán'. }\end{array}$ \\
\hline \multicolumn{2}{|c|}{$\begin{array}{l}\text { Enseñar habilidades de resolución de } \\
\text { problemas }\end{array}$} & $\begin{array}{l}\text { Incluye: adopción de otras perspectivas, control de los impulsos, comunicación } \\
\text { efectiva, regulación de las emociones, tolerancia a la frustración, asertividad, } \\
\text { pensamiento consecuencial, posponer la acción -para pensar antes- y } \\
\text { reestructuración cognitiva. }\end{array}$ \\
\hline \multicolumn{2}{|c|}{ Disminuir la ira y la impulsividad } & $\begin{array}{l}\text { Responder a las acciones impulsivas y a la ira del paciente de una forma amable, } \\
\text { pero directa ofreciendo una visión alternativa, sistemática y cientifica que valore } \\
\text { las ventajas y desventajas de la conducta. } \\
\text { Enseñarles a prestar atención a las claves emocionales y cognitivas internas, } \\
\text { evaluar su percepción, decidir si vale la pena responder, identificar posibles } \\
\text { respuestas, escoger una respuesta, y responder. }\end{array}$ \\
\hline \multicolumn{2}{|c|}{$\begin{array}{l}\text { Aumentar la introspección y la conciencia } \\
\text { acerca de las diferentes funciones de sus } \\
\text { pautas de conducta }\end{array}$} & $\begin{array}{l}\text { Enseñarles a observar sus acciones y suponer cuáles son las funciones y } \\
\text { recompensas de determinadas cadenas de conductas. } \\
\text { Aprender a escucharse a ellos mismos y a desarrollar las habilidades necesarias } \\
\text { para examinar lo que piensan y sienten. }\end{array}$ \\
\hline $\begin{array}{l}\text { Ampliar la base para las } \\
\text { atribuciones y } \\
\text { valoraciones }\end{array}$ & $\begin{array}{l}\text { Incrementar el } \\
\text { rango de intereses }\end{array}$ & $\begin{array}{l}\text { Utilizar una jerarquía ampliada basada en teorías sobre el desarrollo moral y } \\
\text { cognitivo, que vaya desde lo que el paciente piensa sólo en términos de su } \\
\text { propio interés -nivel inferior- hasta lo que demuestre un interés por los otros y un } \\
\text { respeto a sus necesidades y deseos -nivel superior-. El terapeuta va guiando al } \\
\text { paciente hacia niveles superiores, alentándole a ensayar soluciones alternativas } \\
\text { capaces de modificar sus reglas de vida anteriores. }\end{array}$ \\
\hline $\begin{array}{l}\text { Tomar decisiones } \\
\text { constructivas }\end{array}$ & $\begin{array}{l}\text { Aprender a ver los } \\
\text { problemas como un } \\
\text { conjunto de } \\
\text { elecciones }\end{array}$ & $\begin{array}{l}\text { Llevar a cabo una revisión sistemática de la razón 'riesgo-beneficio' de las } \\
\text { diferentes elecciones. } \\
\text { El ejercicio de 'revisión de elecciones' puede adaptarse o modificarse para } \\
\text { atender a las necesidades especiales de cada paciente. }\end{array}$ \\
\hline
\end{tabular}


Trastorno Límite de la Personalidad, en base a Arntz (2005).

\begin{tabular}{|c|c|c|c|}
\hline \multicolumn{4}{|c|}{ PERFIL COGNITIVO } \\
\hline \multicolumn{2}{|c|}{ Concepción de sí mismo } & \multicolumn{2}{|c|}{$\begin{array}{l}\text { Vulnerable -al rechazo, a la traición, a la dominación-. Carente de un apoyo emocional que necesita. } \\
\text { Privado de capacidad y fuerza. Fuera de control. Defectuoso. Imposible de amar. Malo. }\end{array}$} \\
\hline \multicolumn{2}{|c|}{$\begin{array}{l}\text { Concepción de los } \\
\text { demás }\end{array}$} & \multicolumn{2}{|c|}{$\begin{array}{l}\text { Idealizados: capacitados, dignos de amor, perfectos. } \\
\text { Devaluados: controladores, traidores, que abandonan, que rechazan. }\end{array}$} \\
\hline \multirow{2}{*}{\multicolumn{2}{|c|}{ Principales Creencias }} & $\begin{array}{l}\text { Supuestos } \\
\text { claves }\end{array}$ & $\begin{array}{l}\text { 'El mundo es peligroso y malo'. } \\
\text { 'Soy impotente y vulnerable'. 'Soy intrinsecamente inaceptable'. }\end{array}$ \\
\hline & & $\begin{array}{l}\text { Otros } \\
\text { supuestos }\end{array}$ & $\begin{array}{l}\text { 'Si me fío de alguien, me maltratará y abandonará'. 'Lo peor que le puede } \\
\text { pasar a uno es que lo abandones'. 'Me resulta imposible controlarme a mi } \\
\text { mismo'. 'Merezco que me castiguen'. 'No puedo manejarme solo'. 'Necesito } \\
\text { alguien en quien confiar'.'No puedo soportar los sentimientos desagradables'. }\end{array}$ \\
\hline \multicolumn{2}{|c|}{$\begin{array}{l}\text { Características } \\
\text { Cognitivas }\end{array}$} & \multicolumn{2}{|c|}{$\begin{array}{l}\text { Alto nivel de vigilancia. Desconfianza interpersonal excesiva. Pensamiento dicotómico. Débil sentido de } \\
\text { identidad. }\end{array}$} \\
\hline \multicolumn{2}{|c|}{$\begin{array}{l}\text { Estrategias } \\
\text { sobredesarrolladas }\end{array}$} & \multicolumn{2}{|c|}{$\begin{array}{l}\text { Subyugar las propias necesidades para mantener la relación. } \\
\text { Protestar teatralmente, amenazar y ser violento con aquellos que den signos de un posible rechazo. } \\
\text { Aliviarse a través de la autolesión y la conducta autodestructiva. } \\
\text { Intentar el suicidio como una forma de escape. }\end{array}$} \\
\hline \multicolumn{4}{|r|}{ CURSO DE TRATAMIENTO } \\
\hline \multicolumn{3}{|c|}{ Objetivos } & Técnicas \\
\hline \multirow[t]{3}{*}{$\begin{array}{l}\text { Aumentar la } \\
\text { colaboración } \\
\text { inicial }\end{array}$} & & $\begin{array}{l}\text { rrollar una relación } \\
\text { onal intensa entre } \\
\text { apeuta y paciente }\end{array}$ & $\begin{array}{l}\text { Enfoque 'reparental': Desarrollar con el paciente un apego seguro como corrección } \\
\text { de lo que sucedió en la infancia, dándole medios para contactar con el terapeuta } \\
\text { cuando se halle emocionalmente necesitado. Esto les ayuda a rechazar la } \\
\text { creencia de que a nadie le importan, y que la expresión de sentimientos negativos } \\
\text { será respondida con castigos y abandono. } \\
\text { Mantener una postura activa y educativa, no moralista, pero capaz de explicar por } \\
\text { qué ciertas posturas y concepciones son más sanas que otras. } \\
\text { Práctica confrontacional: (1) Expresar empáticamente lo que el terapeuta piensa } \\
\text { acerca de por qué se escoge determinada estrategia disfuncional; (2) confrontar } \\
\text { con los efectos negativos de la estrategia y la continuación del trastorno; ( } 3 \text { ) } \\
\text { formular explícitamente una nueva estrategia alternativa funcional para pedirle } \\
\text { después al paciente que la siga. }\end{array}$ \\
\hline & $\begin{array}{r}\text { Enseñ } \\
\text { se }\end{array}$ & $\begin{array}{l}\text { a tolerar y aceptar las } \\
\text { aciones negativas }\end{array}$ & Hablarles y escucharles con plena aceptación en sus momentos de crisis. \\
\hline & Preve & $\begin{array}{l}\text { Ir el abandono precoz } \\
\text { de la terapia }\end{array}$ & $\begin{array}{l}\text { Llamar al paciente cuando no se presente a las sesiones, preguntarle qué razones } \\
\text { tiene para abandonar y adaptarse a lo que el paciente necesita. }\end{array}$ \\
\hline \multicolumn{3}{|c|}{$\begin{array}{l}\text { Planificar la terapia ordenando jerárquicamente, } \\
\text { según prioridad, cada tema a trabajar }\end{array}$} & $\begin{array}{l}\text { Enfoque jerárquico: planificar la terapia estableciendo una jerarquia de los temas a } \\
\text { tratar: } 1^{\circ} \text { temas sobre actitudes que significan una amenaza para la vida; } 2^{\circ} \\
\text { relación terapéutica; } 3^{\circ} \text { temas sobre actitudes que llevan a la autolesión; } 4^{\circ} \text { otros } \\
\text { temas, trabajo sobre los esquemas y procesos de trauma. }\end{array}$ \\
\hline \multirow{2}{*}{ Manejar las crisis } & $\begin{array}{r}\text { Cont } \\
\text { negati } \\
\text { de }\end{array}$ & $\begin{array}{l}\text { Irestar las creencias } \\
\text { as del paciente acerca } \\
\text { experiencia de las } \\
\text { emociones }\end{array}$ & $\begin{array}{l}\text { Adoptar, por parte del terapeuta, una postura sosegada y acogedora, escucharle de } \\
\text { forma empática, preguntarle cómo se siente y qué interpretación hace de lo que le } \\
\text { ocurre, validando sus sentimientos. Asimismo, preguntar directamente por ideas y } \\
\text { pensamientos autopunitivos y contrarrestarlos. }\end{array}$ \\
\hline & $\begin{array}{r}\text { Prev } \\
\text { aut }\end{array}$ & $\begin{array}{l}\text { nir empeoramientos, } \\
\text { lesiones, abuso de } \\
\text { sustancias }\end{array}$ & $\begin{array}{l}\text { Disponibilidad del terapeuta: Darle al paciente algún medio para comunicarse, } \\
\text { permite realizar una intervención temprana y ayudar así a reducir a necesidad de } \\
\text { hospitalización. En muchos casos, una escucha empática y hablar con el paciente } \\
\text { por teléfono acaba con la crisis en cuestión de minutos. }\end{array}$ \\
\hline \multicolumn{3}{|c|}{ Establecer limites } & $\begin{array}{l}\text { Limitar conductas inaceptables como aquellas que traspasan la frontera de la } \\
\text { integridad del terapeuta y las acciones peligrosas. } \\
\text { Mencionar las razones de la imposición de límites, refiriéndose siempre a la } \\
\text { conducta del paciente y no criticar su carácter. }\end{array}$ \\
\hline \multirow{3}{*}{$\begin{array}{l}\text { Técnicas } \\
\text { cognitivas }\end{array}$} & & $\begin{array}{l}\text { svelar esquemas } \\
\text { subyacentes }\end{array}$ & $\begin{array}{l}\text { Llevar un diario de emociones, pensamientos y conductas para poder comprender } \\
\text { las propias emociones, pensamientos y conductas. }\end{array}$ \\
\hline & & $\begin{array}{l}\text { atir el pensamiento } \\
\text { dicotómico }\end{array}$ & $\begin{array}{l}\text { Aumentar la conciencia del paciente acerca de este estilo de pensamiento y sus } \\
\text { implicaciones negativas, y luego realizar ejercicios estructurados para desarrollar } \\
\text { un estilo de pensamiento más adaptativo. }\end{array}$ \\
\hline & $\begin{aligned} A_{1} \\
\text { alter }\end{aligned}$ & $\begin{array}{l}\text { car los esquemas } \\
\text { ativos aprendidos en } \\
\text { terapia }\end{array}$ & $\begin{array}{l}\text { Tarjetas educativas: En una cara se describe el razonamiento patógeno y el } \\
\text { esquema activado, lo que causa determinada emoción. En la otra, la visión sana, } \\
\text { junto con una manera funcional de manejar los problemas. }\end{array}$ \\
\hline \multirow{3}{*}{$\begin{array}{l}\text { Técnicas } \\
\text { experienciales }\end{array}$} & $\begin{array}{r}\text { Mo } \\
\text { infanti }\end{array}$ & $\begin{array}{l}\text { ficar los recuerdos } \\
\text { s dolorosos en cuanto } \\
\text { esquemas }\end{array}$ & $\begin{array}{l}\text { Reescritura del pasado y 'role play' histórico: Se toma un sentimiento negativo } \\
\text { presente como puente mnemónico para llegar a un recuerdo infantil que el } \\
\text { paciente imagina con los ojos cerrados, y así intervenir en dicha escena. }\end{array}$ \\
\hline & sentim & $\begin{array}{l}\text { oresar libremente } \\
\text { ntos y opiniones sobre } \\
\text { figuras punitivas }\end{array}$ & $\begin{array}{l}\text { Técnica de la silla vacía: Se representan simbólicamente a los cuidadores punitivos } \\
\text { o personas amenazadoras del presente para que, terapeuta y/o paciente, puedan } \\
\text { expresar lo que sienten y opinan sobre ello. }\end{array}$ \\
\hline & & $\begin{array}{l}\text { ender a tolerar las } \\
\text { ociones negativas }\end{array}$ & $\begin{array}{l}\text { Técnicas de exposición: Ejercicios de escritura -de una carta al antiguo maltratador- } \\
\text { y modelar verbalmente la expresión de la ira. }\end{array}$ \\
\hline \multirow{2}{*}{$\begin{array}{l}\text { Técnicas } \\
\text { conductuales }\end{array}$} & & $\begin{array}{l}\text { ender habilidades } \\
\text { nterpersonales }\end{array}$ & $\begin{array}{l}\text { 'Role plays' o escenificación: Normalmente, el terapeuta comienza por modelar la } \\
\text { expresión de la asertividad. }\end{array}$ \\
\hline & Reforz & $\begin{array}{l}\text { los nuevos esquemas } \\
\text { y estrategias }\end{array}$ & $\begin{array}{l}\text { Experimentar con nueva conducta: Se le pide al paciente que ponga en práctica las } \\
\text { nuevas conductas aprendidas. }\end{array}$ \\
\hline
\end{tabular}




\section{Trastorno Histriónico de la Personalidad, en base a Fleming (2005).}

\begin{tabular}{|c|c|c|c|}
\hline \multicolumn{4}{|r|}{ PERFIL COGNITIVO } \\
\hline \multirow{2}{*}{\multicolumn{2}{|c|}{$\begin{array}{l}\text { Concepción de sí mismo } \\
\text { Concepción de los demás }\end{array}$}} & \multicolumn{2}{|c|}{ Encantador. Impresionante. Sociable, amistoso y agradable. } \\
\hline & & \multicolumn{2}{|c|}{ Accesibles a la seducción. Receptivos. Admiradores. } \\
\hline \multirow{2}{*}{\multicolumn{2}{|c|}{ Principales Creencias }} & $\begin{array}{l}\text { Supuestos } \\
\text { subyacentes }\end{array}$ & $\begin{array}{l}\text { 'Yo soy inadecuado e incapaz de manejar la vida por mí mismo'. 'Si no } \\
\text { soy capaz de cuidarme por mí mismo, necesito encontrar el modo de que } \\
\text { otros me cuiden'. }\end{array}$ \\
\hline & & Nucleares & $\begin{array}{l}\text { 'La gente está para servirme o admirarme'. } \\
\text { 'La gente no tiene derecho a negarme lo que me merezco'. } \\
\text { 'Puedo guiarme por mis sentimientos'. } \\
\text { 'Debo buscar la atención y aprobación de los otros, para asegurarme que } \\
\text { satisfagan mis necesidades'. 'Necesito ser amado por todos y siempre-'. }\end{array}$ \\
\hline \multicolumn{2}{|c|}{ Características Cognitivas } & \multicolumn{2}{|c|}{$\begin{array}{l}\text { Estilo cognitivo global, difuso y basado en impresiones con independencia del contenido. } \\
\text { Pensamiento dicotómico. }\end{array}$} \\
\hline \multicolumn{2}{|c|}{$\begin{array}{c}\text { Estrategias } \\
\text { sobredesarrolladas }\end{array}$} & \multicolumn{2}{|c|}{ Teatralidad, encanto; estallidos de mal genio; Ilanto; gestos suicidas. } \\
\hline \multicolumn{4}{|c|}{ CURSO DE TRATAMIENTO } \\
\hline \multicolumn{3}{|c|}{ Objetivos } & Técnicas \\
\hline \multirow{2}{*}{$\begin{array}{l}\text { Aumentar la } \\
\text { colaboración } \\
\text { inicial }\end{array}$} & \multicolumn{2}{|c|}{$\begin{array}{l}\text { Evitar la creencia de que el } \\
\text { terapeuta es un 'salvador } \\
\text { omnipotente' }\end{array}$} & $\begin{array}{l}\text { Pedirle al paciente que desempeñe un rol activo en la terapia. } \\
\text { Empleo coherente de la cooperación y el descubrimiento guiado. }\end{array}$ \\
\hline & \multicolumn{2}{|c|}{$\begin{array}{l}\text { Aprender a ser asertivo y a } \\
\text { solucionar problemas }\end{array}$} & $\begin{array}{l}\text { Reforzar al paciente por su capacidad para atender a los detalles en las } \\
\text { sesiones de terapia. Enseñarles que prestar atención a los detalles y la } \\
\text { asertividad, tiene sus recompensas. }\end{array}$ \\
\hline \multicolumn{3}{|c|}{$\begin{array}{l}\text { Aprender a enfocar la atención en un problema } \\
\text { por vez }\end{array}$} & $\begin{array}{l}\text { Establecer una agenda de temas, permite centrar la atención en temas } \\
\text { especificos. }\end{array}$ \\
\hline \multicolumn{3}{|c|}{$\begin{array}{l}\text { Evitar el abandono de la terapia antes de que se } \\
\text { produzcan cambios significativos }\end{array}$} & $\begin{array}{l}\text { Establecer en el tratamiento metas auténticamente significativas e } \\
\text { importantes para el paciente y que permitan obtener algunos beneficios más o } \\
\text { menos inmediatos, además de ventajas a largo plazo. Es importante que } \\
\text { dichas metas sean especificas y concretas y que tengan una significación real } \\
\text { para el paciente. }\end{array}$ \\
\hline \multirow{3}{*}{$\begin{array}{l}\text { Modificar las } \\
\text { emociones } \\
\text { desencadenadas } \\
\text { por } \\
\text { pensamientos } \\
\text { disfuncionales }\end{array}$} & $\begin{array}{r}\text { Adqu } \\
\text { identif } \\
\text { pensam }\end{array}$ & $\begin{array}{l}\text { la capacidad de } \\
\text { ir y cuestionar los } \\
\text { ntos disfuncionales }\end{array}$ & $\begin{array}{l}\text { Enseñarle a controlar y puntualizar con exactitud pensamientos especificos. } \\
\text { Enseñarles a observar los pensamientos por medio de un registro de } \\
\text { pensamientos disfuncionales (RPD), especificando los acontecimientos, los } \\
\text { pensamientos y los sentimientos en las primeras tres columnas. EI RPD } \\
\text { puede ser útil para ayudar a los pacientes a no confundir la realidad con sus } \\
\text { fantasías extremas, y a juzgar con más exactitud las atribuciones de causa y } \\
\text { efecto. } \\
\text { Otro método puede ser la realización de experimentos conductuales } \\
\text { dramáticos. }\end{array}$ \\
\hline & \multicolumn{2}{|c|}{$\begin{array}{l}\text { Mejorar la capacidad de } \\
\quad \text { autocontrol }\end{array}$} & $\begin{array}{l}\text { Enumeración de las ventajas y las desventajas de las diferentes opciones: } \\
\text { Esta técnica conviene introducirla al principio del tratamiento, en cuanto el } \\
\text { paciente se resista a mantener la atención sobre el tema acordado. Así, } \\
\text { realizando elecciones conscientes dentro de la sesión de terapia mediante el } \\
\text { examen de ventajas y desventajas de los diversos cursos de acción, el } \\
\text { paciente se prepara para elegir y resolver activamente los problemas también } \\
\text { en la vida cotidiana. } \\
\text { Entrenamiento en habilidades especificas de resolución de problemas: ya que } \\
\text { pocas veces tienen conciencia de las consecuencias antes de actuar, les } \\
\text { resulta útil aprender el 'pensamiento de medios y fines'. Este procedimiento } \\
\text { supone generar una variedad de soluciones posibles -medios- para un } \\
\text { problema, y después evaluar con exactitud las consecuencias probables - } \\
\text { fines- de las diversas alternativas. }\end{array}$ \\
\hline & $\begin{array}{r}\text { Aumer } \\
\text { necesid } \\
p\end{array}$ & $\begin{array}{l}\text { r el sentido de sus } \\
\text { les, deseos y de su } \\
\text { pia identidad }\end{array}$ & $\begin{array}{l}\text { El entrenamiento asertivo eficaz supone el empleo de métodos cognitivos } \\
\text { para ayudarles a prestar atención a lo que quieren y a iniciar el desarrollo de } \\
\text { un sentido de identidad, además de los métodos conductuales para } \\
\text { enseñarles a comunicarse de un modo más adecuado. } \\
\text { Puede ser útil describir el desarrollo del sentido de la identidad simplemente } \\
\text { como la suma total de muchas cosas diversas que no sabe acerca de sí } \\
\text { mismo y empezar a listar algunas de ellas en la sesión, empezando por ítems } \\
\text { frívolos y concretos, como los colores y comidas favoritos, etc. }\end{array}$ \\
\hline \multirow{2}{*}{$\begin{array}{l}\text { Mejorar las } \\
\text { relaciones } \\
\text { interpersonales }\end{array}$} & \multicolumn{2}{|c|}{$\begin{array}{l}\text { Cuestionar la creencia de que } \\
\text { la pérdida de una relación } \\
\text { sería desastrosa }\end{array}$} & $\begin{array}{l}\text { El fantaseo sobre lo que sucedería en realidad si una relación se cortara, y el } \\
\text { recuerdo del modo como se sobrevivía antes del comienzo de esa relación, } \\
\text { son dos métodos muy útiles para ayudar al paciente a 'descatastrofizar' la } \\
\text { idea del rechazo. } \\
\text { Otro método útil consiste en idear experimentos conductuales que } \\
\text { deliberadamente susciten pequeños 'rechazos', de modo que el paciente } \\
\text { pueda realmente practicar sentirse rechazado sin quedar destrozado. }\end{array}$ \\
\hline & \multicolumn{2}{|c|}{$\begin{array}{l}\text { Aprender a cuestionar su } \\
\text { supuesto fundamental: 'Soy } \\
\text { inadecuado y para sobrevivir } \\
\text { tengo que apoyarme en otros' }\end{array}$} & $\begin{array}{l}\text { La asetividad, la resolución de problemas y los experimentos conductuales, } \\
\text { tienen la finalidad de acrecentar la capacidad del paciente para el manejo } \\
\text { exitoso y, de tal modo, ayudarlo a experimentar una sensación de aptitud. } \\
\text { También suele resultar útil emprender experimentos conductuales pequeños y } \\
\text { concretos cuya meta explícita es combatir la idea de que no pueden ser } \\
\text { independientes. }\end{array}$ \\
\hline
\end{tabular}


Trastorno Narcisista de la Personalidad, en base a Davis (2005).

\begin{tabular}{|c|c|c|c|}
\hline \multicolumn{4}{|r|}{ PERFIL COGNITIVO } \\
\hline \multirow{2}{*}{\multicolumn{2}{|c|}{$\begin{array}{l}\text { Concepción de sí mismo } \\
\begin{array}{c}\text { Concepción de los } \\
\text { demás }\end{array}\end{array}$}} & \multirow{2}{*}{\multicolumn{2}{|c|}{$\begin{array}{l}\text { Especial, único. Merece reglas especiales, es superior. Está por encima de las reglas. } \\
\text { Inferiores. Admiradores. }\end{array}$}} \\
\hline & & & \\
\hline \multirow{3}{*}{\multicolumn{2}{|c|}{ Principales Creencias }} & Nucleares & $\begin{array}{l}\text { La creencia nuclear de este trastorno es la de sentirse interior o } \\
\text { irrelevante. Esta creencia sólo se activa bajo ciertas circunstancias en } \\
\text { que la autoestima se ve amenazada. De otra manera, esta creencia se } \\
\text { manifiesta en una actitud compensatoria de superioridad: 'Soy una } \\
\text { persona exclusiva y especial' o 'Soy superior a los demás'. Otra creencia } \\
\text { compensatoria es: 'Los demás deberían reconocer lo especial que soy'. }\end{array}$ \\
\hline & & Condicionales & $\begin{array}{l}\text { Evidencia de superioridad: Asumen que ciertas circunstancias o hechos } \\
\text { tangibles le proporcionan evidencia de que es superior: 'Debo tener éxito } \\
\text { para probar mi superioridad'; 'Si no tengo éxito, no valgo nada'. } \\
\text { Las relaciones son herramientas: Creen que las personas son objetos o } \\
\text { herramientas útiles en la búsqueda de distinción, por lo que gastan } \\
\text { mucha energia mental comparándose y juzgando la valia propia y la de } \\
\text { los demás. } \\
\text { Poder y derechos: Usan el poder que puedan detentar como evidencia de } \\
\text { su superioridad: 'Si soy suficientemente poderoso, tendré total confianza } \\
\text { en mí mismo y estaré libre de dudas'. } \\
\text { Cuidado de la imagen: Creen que 'la imagen lo es todo', porque es la } \\
\text { armadura de su autoestima. Por lo tanto, su principal preocupación es } \\
\text { comprobar y mantener su imagen. } \\
\text { El supuesto de la contribución meritoria: Exageran las necesidades y } \\
\text { debilidades de los demás, y subrayan las propias virtudes y méritos: 'Me } \\
\text { necesitan'; 'Les estoy haciendo un favor'. } \\
\text { El supuesto del afecto negativo: Tienden a exagerar las implicaciones } \\
\text { negativas de emociones como tristeza, culpa e indecisión, porque } \\
\text { piensan que esos sentimientos son muestras de debilidad personal que } \\
\text { van en detrimento de una imagen positiva. Por otro lado, obvian los } \\
\text { posibles riesgos asociados a la ira desenfrenada o al autobombo } \\
\text { excesivo: 'Si se quiere algo es muy importante conseguirlo' y 'Debo } \\
\text { sentirme feliz y cómodo todo el tiempo' y 'Si no soy feliz, nadie puede } \\
\text { serlo' y 'Para ser feliz tengo que sentirme especial'. }\end{array}$ \\
\hline & & $\begin{array}{l}\text { Estrategias } \\
\text { Compensatorias }\end{array}$ & $\begin{array}{l}\text { De confirmación: Buscan la confirmación de su poder e importancia } \\
\text { solicitando halagos, comportándose de manera arrogante y } \\
\text { condescendiente en relación a las personas que se hallan en posiciones } \\
\text { subordinadas: 'Mirad lo importante e influyente que soy!'. } \\
\text { De publicidad: Consideran muy importante acumular todo tipo d simbolos } \\
\text { de estatus, perfección y poder -ya sea q dan relevancia a las posesiones } \\
\text { materiales o a los logros y reconocimiento por parte de los demás-. } \\
\text { De protección: El objetivo de estas estrategias es evitar las amenazas a } \\
\text { su perfecta imagen personal. Por lo tanto, responde a la } \\
\text { retroalimentación o comentarios valorativos de manera violenta, ya sea } \\
\text { verbal o físicamente. }\end{array}$ \\
\hline $\begin{array}{c}\text { Caracteristicas } \\
\text { Cognitivas }\end{array}$ & & \multicolumn{2}{|c|}{$\begin{array}{l}\text { Alto nivel de vigilancia. Desconfianza interpersonal excesiva. Pensamiento dicotómico. Débil } \\
\text { sentido de identidad. }\end{array}$} \\
\hline \multicolumn{2}{|c|}{$\begin{array}{c}\text { Estrategias } \\
\text { sobredesarrolladas }\end{array}$} & \multicolumn{2}{|c|}{ Usar a los demás. Saltarse las reglas. Manipular. Competir. } \\
\hline \multicolumn{4}{|c|}{ CURSO DE TRATAMIENTO } \\
\hline \multicolumn{3}{|c|}{ Objetivos } & Técnicas \\
\hline \multicolumn{3}{|c|}{ Aumentar la colaboración inicial } & $\begin{array}{l}\text { Brindar apoyo al paciente y reforzar sus cualidades, así como ser flexible y } \\
\text { variar la estructura del trabajo cuando sea necesario. } \\
\text { Formular reflexiones y comentarios favorables para adaptarse al estilo de } \\
\text { relación que le gusta al paciente. }\end{array}$ \\
\hline \multicolumn{3}{|c|}{ Formular objetivos limitados y establecer prioridades } & $\begin{array}{l}\text { Establecer una lista concreta de problemas basada en las dificultades } \\
\text { especificas que presenta el paciente. }\end{array}$ \\
\hline \multicolumn{3}{|c|}{$\begin{array}{l}\text { Evaluar creencias narcisistas especificas y } \\
\text { determinar su intensidad }\end{array}$} & $\begin{array}{l}\text { Se puede utilizar una herramienta estructurada como el Personality Belief } \\
\text { Questionnaire -PBQ- }\end{array}$ \\
\hline \multicolumn{3}{|c|}{$\begin{array}{l}\text { Mejorar las habilidades para lograr objetivos y } \\
\text { revisar el significado del éxito }\end{array}$} & $\begin{array}{l}\text { Pueden utilizarse estrategias de trabajo cognitivas y conductuales: gráficos de } \\
\text { queso, experimentos y descubrimiento guiado, analizar costes/beneficios de } \\
\text { las conductas, explorar y confrontar ideas subyacentes, etc. }\end{array}$ \\
\hline \multicolumn{3}{|c|}{$\begin{array}{l}\text { Adquirir empatía y entender los limites y las } \\
\text { perspectivas } \\
\text { de los demás }\end{array}$} & $\begin{array}{l}\text { Resultan muy útiles los role plays, sobre todo cuando se escenifica la postura } \\
\text { de la otra persona. } \\
\text { Pedir feedback al paciente durante las sesiones. Se indicará que los juicios y } \\
\text { comparaciones son violaciones de lo límites emocionales de las } \\
\text { interacciones, y que es más útil, respetuoso y empático hacer descripciones } \\
\text { no evaluativas que muevan a la aceptación. }\end{array}$ \\
\hline $\begin{array}{l}\text { Modificar creencias } \\
\text { disfuncionales } \\
\text { acerca del yo y las } \\
\text { emociones }\end{array}$ & & $\begin{array}{l}\text { Explorar creencias y } \\
\text { supuestos } \\
\text { de grandiosidad y } \\
\text { arrollar alternativas más } \\
\quad \text { adaptativas }\end{array}$ & $\begin{array}{l}\text { Se pueden utilizar preguntas de descubrimiento personal. Asimismo, puede } \\
\text { resultar útil decirles que en ciertas circunstancias y en ciertos ámbitos, hasta } \\
\text { las personas más exitosas se replantean sus decisiones. Por ejemplo, } \\
\text { cuando se encuentran en callejones sin salida o en el contexto de las } \\
\text { relaciones. }\end{array}$ \\
\hline
\end{tabular}


Trastorno de la Personalidad por Dependencia, en base a Fleming (2005).

\begin{tabular}{|c|c|c|c|}
\hline \multicolumn{4}{|c|}{ PERFIL COGNITIVO } \\
\hline \multirow{2}{*}{\multicolumn{2}{|c|}{$\begin{array}{l}\text { Concepción de sí mismo } \\
\text { Concepción de los demás }\end{array}$}} & \multicolumn{2}{|c|}{ Necesitados. Débiles. Desvalidos. Incompetentes. } \\
\hline & & \multicolumn{2}{|c|}{ Idealizados. Generosos. Brindan apoyo. Competentes. } \\
\hline \multirow{3}{*}{\multicolumn{2}{|c|}{ Principales Creencias }} & Nucleares & $\begin{array}{l}\text { Estoy completamente desamparado'. } \\
\text { 'Estoy solo'. } \\
\text { 'Para sobrevivir necesito de otra persona, una persona fuerte'. } \\
\text { 'Necesito de la gente para sobrevivir, para ser feliz'. } \\
\text { 'Necesito de un flujo constante de apoyo, de aliento'. } \\
\end{array}$ \\
\hline & & Condicionales & $\begin{array}{l}\text { Sólo puedo funcionar si tengo acceso a alguien competente'. } \\
\text { 'Si me abandonan, moriré'. } \\
\text { 'Si no soy amado, siempre seré infeliz'. } \\
\text { 'Si fuera más independiente, estaría aislado y solo'. }\end{array}$ \\
\hline & & $\begin{array}{l}\text { Instrumentales o } \\
\text { de Autoinstrucción }\end{array}$ & $\begin{array}{l}\text { No ofender al cuidador'. } \\
\text { 'Permanecer cerca'. } \\
\text { 'Cultivar la relación más intima posible'. } \\
\text { 'Ser sumiso para tenerlo atado'. }\end{array}$ \\
\hline \multicolumn{4}{|c|}{ Características Cognitivas } \\
\hline \multicolumn{2}{|c|}{$\begin{array}{c}\text { Estrategias } \\
\text { sobredesarrolladas }\end{array}$} & \multicolumn{2}{|c|}{ Establecer una relación de dependencia. } \\
\hline \multicolumn{4}{|c|}{ CURSO DE TRATAMIENTO } \\
\hline \multicolumn{2}{|c|}{ Objetivos } & \multicolumn{2}{|r|}{ Técnicas } \\
\hline \multirow{3}{*}{$\begin{array}{l}\text { Establecer relación } \\
\text { terapéutica }\end{array}$} & $\begin{array}{l}\text { Conceder cierta } \\
\text { dependencia al principio del } \\
\text { tratamiento }\end{array}$ & & $\begin{array}{l}\text { blecer una guía activa y sugerencias prácticas para implicar al } \\
\text { iente en el tratamiento. } \\
\text { ar el uso de términos como: dependencia, independencia, autonomía } \\
\text { a no asustar al paciente al inicio del tratamiento. }\end{array}$ \\
\hline & $\begin{array}{l}\text { Acrecentar su autoconfianza } \\
\text { y sentido de la propia } \\
\text { eficacia }\end{array}$ & & $\begin{array}{l}\text { rogación socrática y el descubrimiento guiado: para que el paciente a } \\
\text { lore sus pensamientos y sentimientos respecto del terapeuta y } \\
\text { bién respecto de otras relaciones. }\end{array}$ \\
\hline & $\begin{array}{l}\text { Pactar límites claros en la } \\
\text { relación }\end{array}$ & & $\begin{array}{l}\text { ejar la situación con cuidado y reflexión, reconociendo los } \\
\text { timientos del paciente y explicándole que esas reacciones son } \\
\text { nunes a la terapia. }\end{array}$ \\
\hline \multirow{5}{*}{$\begin{array}{l}\text { Refutar creencias } \\
\text { disfuncionales sobre } \\
\text { su desvalimiento }\end{array}$} & $\begin{array}{l}\text { Conceder un papel más } \\
\text { activo }\end{array}$ & \multicolumn{2}{|r|}{$\begin{array}{l}\text { Alentar al paciente a aportar objetivos, sugerencias y deberes para } \\
\text { realizar entre sesión y sesión. Confeccionar una agenda sobre los } \\
\text { temas a tratar en cada sesión y sus sugerencias. }\end{array}$} \\
\hline & $\begin{array}{l}\text { Reunir pruebas de su } \\
\text { capacidad personal }\end{array}$ & \multicolumn{2}{|r|}{$\begin{array}{l}\text { Jerarquía de toma de decisiones que permita establecer acciones } \\
\text { independientes cada vez más difíciles. }\end{array}$} \\
\hline & $\begin{array}{l}\text { Identificar y evaluar } \\
\text { pensamientos automáticos } \\
\text { que interfieren en una tarea }\end{array}$ & \multicolumn{2}{|r|}{$\begin{array}{l}\text { Lista de ventajas y desventajas de llevar un registro de pensamientos } \\
\text { disfuncionales para reemplazarlos por otros. } \\
\text { Realizar experimentos conductuales en las sesiones para cuestionar los } \\
\text { pensamientos automáticos disfuncionales. }\end{array}$} \\
\hline & $\begin{array}{l}\text { Incrementar habilidades } \\
\text { generales para mejorar su } \\
\text { competencia y promover su } \\
\text { autoevaluación }\end{array}$ & \multicolumn{2}{|r|}{$\begin{array}{l}\text { Entrenamiento en asertividad, resolución de problemas, toma de } \\
\text { decisiones e interacción social. } \\
\text { Enseñar habilidades de autocontrol para que el paciente pueda advertir } \\
\text { sus cambios y mejoría. }\end{array}$} \\
\hline & $\begin{array}{l}\text { Trabajar sobre el miedo de } \\
\text { avanzar con rapidez en la } \\
\text { terapia }\end{array}$ & \multicolumn{2}{|r|}{$\begin{array}{l}\text { Lista de ventajas y desventajas de cambiar, explorando seriamente las } \\
\text { desventajas que supone alcanzar las metas. }\end{array}$} \\
\hline \multirow{2}{*}{$\begin{array}{l}\text { Explorar las } \\
\text { características } \\
\text { cognitivas que } \\
\text { presentan estos } \\
\text { pacientes para } \\
\text { modificarlas }\end{array}$} & $\begin{array}{l}\text { Abordar el pensamiento } \\
\text { dicotómico con respecto a la } \\
\text { independencia }\end{array}$ & \multicolumn{2}{|r|}{$\begin{array}{l}\text { Continuo de independencia para descubrir puntos intermedios entre los } \\
\text { dos extremos y sea menos terrorifico avanzar en la terapia en pequeños } \\
\text { pasos. } \\
\text { Dar ejemplos de cómo los adultos independientes toman medidas para } \\
\text { asegurarse ayuda cuando la necesitan. }\end{array}$} \\
\hline & $\begin{array}{l}\text { Abordar el catastrofismo de } \\
\text { que si es más competente } \\
\text { será abandonado }\end{array}$ & \multicolumn{2}{|r|}{$\begin{array}{l}\text { Experimentos conductuales en los que se comporte con algo más de } \\
\text { capacidad y observe la reacción de los demás. } \\
\text { Terapia conyugal o familiar para que los demás se adapten a los cambios } \\
\text { del paciente -en el caso de que reaccionen negativamente a la nueva } \\
\text { conducta de él-. }\end{array}$} \\
\hline
\end{tabular}


Trastorno de la Personalidad por Evitación, en base a Padesky y Beck (2005).

\begin{tabular}{|c|c|c|}
\hline \multicolumn{3}{|c|}{ PERFIL COGNITIVO } \\
\hline Concepción de sí mismo & \multicolumn{2}{|c|}{ Vulnerable al desprestigio y al rechazo. Socialmente inepto. Incompetente en el estudio o trabajo. } \\
\hline Concepción de los demás & \multicolumn{2}{|c|}{ Críticos. Desinteresados. Superiores. Despreciativos o despectivos. } \\
\hline \multirow{3}{*}{ Principales Creencias } & Nucleares & $\begin{array}{l}\text { 'no soy bueno'. } \\
\text { 'soy indigno'. } \\
\text { 'no merezco ser amado'. } \\
\text { 'no tolero los sentimientos desagradables'. }\end{array}$ \\
\hline & Condicionales & $\begin{array}{l}\text { 'si la gente conociera mi verdadero yo me rechazaría'. } \\
\text { 'si emprendo algo nuevo y sin éxito, sería devastador'. }\end{array}$ \\
\hline & Instrumentales o de Autoinstrucción & $\begin{array}{l}\text { 'debo evitar a toda costa las situaciones desagradables'. } \\
\text { 'si pienso o siento que algo es desagradable debo tratar de } \\
\text { suprimirlo enseguida, distrayéndome o con un remedio } \\
\text { rápido'. }\end{array}$ \\
\hline Características Cognitivas & \multicolumn{2}{|c|}{$\begin{array}{l}\text { Negativismo: interpretan de manera negativa las reacciones neutras o positivas y excluyen } \\
\text { cualquier reacción positiva por parte de los demás. } \\
\text { Catastrofismo: Creen que si los demás descubren como son, sería devastador y se perdería la } \\
\text { relación. }\end{array}$} \\
\hline $\begin{array}{c}\text { Estrategias } \\
\text { sobredesarrolladas }\end{array}$ & \multicolumn{2}{|c|}{$\begin{array}{l}\text { Evitar las situaciones de evaluación y grupos sociales. } \\
\text { Evitar los pensamientos o sentimientos desagradables a través de distracciones. }\end{array}$} \\
\hline \multicolumn{3}{|c|}{ CURSO DE TRATAMIENTO } \\
\hline \multicolumn{2}{|c|}{ Objetivos } & Técnicas \\
\hline \multirow{2}{*}{$\begin{array}{l}\text { Establecer una relación } \\
\text { terapéutica }\end{array}$} & $\begin{array}{l}\text { Abordar las creencias } \\
\text { disfuncionales en cuanto al } \\
\text { miedo al rechazo y la } \\
\text { desconfianza por parte de los } \\
\text { demás. }\end{array}$ & $\begin{array}{l}\text { Identificar y poner de manifiesto los pensamientos automáticos } \\
\text { cuando el paciente demuestra cambios de afecto. } \\
\text { Evaluar dichos pensamientos y la retroalimentación } \\
\text { terapéutica. } \\
\text { Formular preguntas directas sobre el miedo a brindar } \\
\text { información. }\end{array}$ \\
\hline & Alentar la asertividad & $\begin{array}{l}\text { Emplear formularios de retroalimentación para el terapeuta } \\
\text { después de cada sesión, basados en una evaluación de } \\
\text { procesos y contenidos de la terapia. } \\
\text { Role-playing y evocación guiada de imágenes para la } \\
\text { asertividad in vivo. }\end{array}$ \\
\hline \multirow[t]{2}{*}{$\begin{array}{l}\text { Ayudar al paciente a superar la } \\
\text { evitación cognitiva y emocional }\end{array}$} & $\begin{array}{l}\text { Identificar y evaluar } \\
\text { pensamientos automáticos y } \\
\text { emociones negativas que } \\
\text { provocan }\end{array}$ & $\begin{array}{l}\text { Evocación de imágenes para registrar y poner a prueba las } \\
\text { creencias que conducen a la evitación. } \\
\text { Diagramar la pauta de evitación: explicar bajo el modelo } \\
\text { cognitivo el circuito de evitación. } \\
\text { Utilizar el descubrimiento guiado para que confirma las } \\
\text { desventajas de la evitación. }\end{array}$ \\
\hline & $\begin{array}{l}\text { Aumentar la tolerancia a la } \\
\text { disforia }\end{array}$ & $\begin{array}{l}\text { Descubrimiento guiado: a medida que se profundiza el análisis } \\
\text { del diagrama de evitación, evocar poco a poco las } \\
\text { emociones negativas y discutir las experiencias que } \\
\text { provocan malestar. }\end{array}$ \\
\hline \multicolumn{2}{|c|}{$\begin{array}{l}\text { Abordar la dificultad del paciente para identificar los } \\
\text { pensamientos y realizar las tareas }\end{array}$} & $\begin{array}{l}\text { Evocación de imágenes para el ensayo y planificación de } \\
\text { tareas. A medida que la tolerancia a los pensamientos } \\
\text { negativos aumenta, enseñar enfoques cognitivos y } \\
\text { conductuales para manejar sus estados de ánimo. } \\
\text { Registro de pensamientos: utilizar esta técnica para detectar y } \\
\text { conectar los pensamientos con sus sentimientos, y } \\
\text { conductas de evitación. } \\
\text { Considerar terapia familiar para poner a prueba la validez de } \\
\text { las creencias y pensamientos sobre los demás. }\end{array}$ \\
\hline \multicolumn{2}{|c|}{$\begin{array}{l}\text { Entrenar al paciente en habilidades para mejorar las } \\
\text { interacciones sociales }\end{array}$} & $\begin{array}{l}\text { Entrenamiento en habilidades sociales: iniciarlo con señales } \\
\text { no verbales y avanzar hasta incluir métodos de } \\
\text { conversación, asertividad y manejo de conflictos. } \\
\text { Brindar instrucciones sobre los métodos de conversación, la } \\
\text { asertividad, la sexualidad y el manejo de conflictos. }\end{array}$ \\
\hline \multirow[b]{2}{*}{$\begin{array}{l}\text { Abordar la rigidez de los } \\
\text { esquemas }\end{array}$} & $\begin{array}{c}\text { Identificar y evaluar las } \\
\text { creencias desadaptativas para } \\
\text { ponerlas a prueba }\end{array}$ & $\begin{array}{l}\text { Poner a prueba sus esquemas: utilizar evocaciones de } \\
\text { imágenes y revisiones históricas para comprender la } \\
\text { evolución de sus creencias hacia la desadaptación. }\end{array}$ \\
\hline & $\begin{array}{l}\text { Reemplazar las mismas por } \\
\text { nuevas creencias funcionales }\end{array}$ & $\begin{array}{l}\text { Identificar nuevas creencias alternativas que el paciente desea } \\
\text { que sean ciertas, mediante un registro de experiencias } \\
\text { positivas. } \\
\text { Contrastar antiguas y nuevas creencias: Poner a prueba los } \\
\text { nuevos esquemas mediante observación guiada y realizar } \\
\text { dramatizaciones de incidentes tempranos relacionados con } \\
\text { las antiguas creencias evitativas. } \\
\text { Orientar al paciente a que advierta y recuerde datos que } \\
\text { apoyen las nuevas creencias. }\end{array}$ \\
\hline
\end{tabular}


Trastorno Obsesivo-Compulsivo de la Personalidad, en base a Simon (2005).

\begin{tabular}{|c|c|c|}
\hline \multicolumn{3}{|c|}{ PERFIL COGNITIVO } \\
\hline Concepción de sí mismo & \multicolumn{2}{|c|}{ Responsable. Rinde cuentas. Fastidioso. Competente. } \\
\hline Concepción de los demás & \multicolumn{2}{|c|}{ Irresponsables. Excesivamente despreocupados. Incompetentes. Autocomplacientes. } \\
\hline \multirow[b]{3}{*}{ Principales Creencias } & \multicolumn{2}{|c|}{\begin{tabular}{|l|l|} 
Nucleares & $\begin{array}{l}\text { 'Puedo verme abrumado' } \\
\text { 'Soy básicamente desorganizado o estoy desorientado' } \\
\text { 'Para sobrevivir necesito orden, sistema y reglas'. } \\
\text { 'Los errores son intolerables'. }\end{array}$ \\
\end{tabular}} \\
\hline & \multicolumn{2}{|c|}{$\begin{array}{l}\text { Si no soy sistemático todo se derrumbará' } \\
\text { 'Cualquier fallo o defecto por mi parte hará que me derrumbe' } \\
\text { 'Si yo u otro no nos esforzamos al máximo, fracasaremos' } \\
\text { 'Si fallo en esto soy un fracaso como persona' } \\
\text { 'Si uno comete un error, se merece ser criticado'. }\end{array}$} \\
\hline & \multicolumn{2}{|c|}{$\begin{array}{l}\text { les o } \\
\text { ción } \\
\text { ciobo ser cuidadoso y meticuloso' } \\
\text { Prácticamente todo tengo que hacerlo a la perfección' } \\
\text { 'Debo percatarme de los errores inmediatamente para estar a tiem } \\
\text { 'Sé qué es lo mejor'. } \\
\text { 'Tienen que hacerlo a mi manera'. } \\
\text { 'Los detalles son esenciales'. } \\
\text { 'La gente deberá trabajar mejor y esforzarse más' } \\
\text { 'Continuamente tengo que empujarme a mí mismo - y empujar a otros-'. } \\
\text { 'Hay que criticar a la gente para evitar errores futuros'. }\end{array}$} \\
\hline Características Cognitivas & \multicolumn{2}{|c|}{$\begin{array}{l}\text { Pensamiento dicotómico: 'Cualquier desviación de lo que está bien, está automáticamente mal'. } \\
\text { Pensamiento mágico: 'Uno puede prevenir los desastres/errores preocupándose por ellos'. Si el } \\
\text { perfecto curso de la acción no está claro, es mejor no hacer nada. }\end{array}$} \\
\hline $\begin{array}{l}\text { Estrategias } \\
\text { sobredesarrolladas }\end{array}$ & \multicolumn{2}{|c|}{$\begin{array}{l}\text { Aplicar las reglas. } \\
\text { Perfeccionismo. } \\
\text { Evaluar y medir el comportamiento de los demás y el suyo propio. } \\
\text { Ejercer el máximo control sobre su propia conducta y la de los otros involucrados. } \\
\text { 'Deberes', criticar, castigar. }\end{array}$} \\
\hline \multicolumn{3}{|c|}{ CURSO DE TRATAMIENTO } \\
\hline \multicolumn{2}{|r|}{ Objetivos } & Técnicas \\
\hline $\begin{array}{l}\text { Establecer una relación } \\
\text { terapéutica }\end{array}$ & $\begin{array}{l}\text { Tener en cuenta la rigidez, la } \\
\text { incomodidad de las emociones para } \\
\text { establecer el rapport }\end{array}$ & $\begin{array}{l}\text { Encarar una terapia de tipo más práctico y centrada en el } \\
\text { problema. } \\
\text { Evitar establecer demasiado pronto una relación emocional } \\
\text { intensa. }\end{array}$ \\
\hline \multirow[b]{2}{*}{$\begin{array}{l}\text { Estructurar las } \\
\text { sesiones de terapia }\end{array}$} & $\begin{array}{l}\text { Identificar las áreas - problema que se } \\
\text { van a abordar }\end{array}$ & $\begin{array}{l}\text { Establecer una agenda con prioridades y utilizar técnica de } \\
\text { resolución de problemas para trabajar con problemas } \\
\text { especificos hasta alcanzar un nivel aceptable. }\end{array}$ \\
\hline & $\begin{array}{l}\text { Establecer metas } \\
\text { concretas a trabajar }\end{array}$ & $\begin{array}{l}\text { Técnica de 'Programa de actividad semanal': para que el } \\
\text { paciente proyecte hora por hora las actividades de la semana } \\
\text { ayudándolo a estructurar su vida, siendo más productivo con } \\
\text { menor esfuerzo. }\end{array}$ \\
\hline \multirow{2}{*}{$\begin{array}{l}\text { Identificar y modificar } \\
\text { las creencias } \\
\text { disfuncionales } \\
\text { subyacentes }\end{array}$} & $\begin{array}{l}\text { Presentar y explicar el modelo } \\
\text { cognitivo al paciente }\end{array}$ & $\begin{array}{l}\text { Ejemplificar el modelo estando alerta a cualquier cambio } \\
\text { afectivo que se produzca en la sesión e indagando en el } \\
\text { paciente sus pensamientos. } \\
\text { Evocación de imágenes: en la que se experimentan diversas } \\
\text { emociones para conectarlas con los pensamientos que } \\
\text { probablemente las producen. }\end{array}$ \\
\hline & $\begin{array}{l}\text { Identificar las dificultades que pueden } \\
\text { surgir en la realización de tareas } \\
\text { relacionadas con la indecisión y la } \\
\text { posposición. }\end{array}$ & $\begin{array}{l}\text { Registro de pensamientos automáticos para relacionar cada } \\
\text { dificultad que tiene en realizar una tarea con los problemas } \\
\text { generales de la indecisión y la posposición. } \\
\text { Experimentos conductuales para poner a prueba esas creencias } \\
\text { y reemplazarlas por otras creencias más funcionales. }\end{array}$ \\
\hline \multirow{3}{*}{$\begin{array}{l}\text { Trabajar sobre la } \\
\text { ansiedad y los } \\
\text { sintomas físicos para } \\
\text { disminuirlos }\end{array}$} & $\begin{array}{l}\text { Identificar el síntoma y la o las } \\
\text { situaciones en que aparece. }\end{array}$ & $\begin{array}{l}\text { Utilizar técnicas de relajación y meditación para aliviar el estrés } \\
\text { y la tensión muscular. }\end{array}$ \\
\hline & $\begin{array}{l}\text { Asociar los sintomas y situaciones } \\
\text { con los pensamientos automáticos } \\
\text { que los provocan }\end{array}$ & $\begin{array}{l}\text { Lista de ventajas y desventajas: con respecto al uso de las } \\
\text { técnicas y también a tener una determinada conducta o } \\
\text { creencia, para evaluar la disfuncionalidad de las mismas y } \\
\text { reemplazarlas por nuevas creencias más adaptativas. }\end{array}$ \\
\hline & $\begin{array}{l}\text { Ayudar al paciente a controlar su } \\
\text { preocupación y rumiación crónicas. }\end{array}$ & $\begin{array}{l}\text { Técnicas de distracción o detención del pensamiento: para } \\
\text { reorientar sus procesos mentales. }\end{array}$ \\
\hline $\begin{array}{l}\text { Abordar las } \\
\text { distorsiones cognitivas } \\
\text { para modificarlas }\end{array}$ & $\begin{array}{l}\text { Contrarrestar el pensamiento } \\
\text { dicotómico y el perfeccionismo }\end{array}$ & $\begin{array}{l}\text { Encargar al paciente la realización de tareas graduales a partir } \\
\text { de la fragmentación de una meta en pasos definibles } \\
\text { especificos. } \\
\text { Observación semanal entre sesiones mediante un registro de } \\
\text { pensamientos disfuncionales para que vea con claridad que } \\
\text { gran parte de su ansiedad y el hecho de posponer la tarea se } \\
\text { deben a su perfeccionismo. }\end{array}$ \\
\hline
\end{tabular}




\section{Trastorno Pasivo-Agresivo o Negativista de la Personalidad, en base a Fusco} (2005).

\begin{tabular}{|c|c|c|}
\hline \multicolumn{3}{|c|}{ CURSO DE TRATAMIENTO } \\
\hline Concepción de sí mismo & \multicolumn{2}{|c|}{ Autosuficientes. Vulnerables al control de otros. } \\
\hline Concepción de los demás & \multicolumn{2}{|c|}{$\begin{array}{l}\text { Intrusivos. Exigentes. Entrometidos. Controladores. Dominantes. Capaces de aprobar, aceptar y } \\
\text { cuidar. }\end{array}$} \\
\hline \multirow{3}{*}{ Principales Creencias } & Nucleares & $\begin{array}{l}\text { 'Tengo que hacer las cosas a mi manera'. } \\
\text { 'Ser controlados por otros es intolerable'. } \\
\text { 'Merezco aprobación por todo lo que he hecho'. }\end{array}$ \\
\hline & Condicionales & $\begin{array}{l}\text { 'Si sigo las reglas pierdo mi libertad de acción'. } \\
\text { 'Si dependo de alguien, no tengo capacidad de decisión'. } \\
\text { 'Si alguien llega a conocerme, seré vulnerable'. }\end{array}$ \\
\hline & $\begin{array}{l}\text { Instrumentales o de } \\
\text { Autoinstrucción }\end{array}$ & $\begin{array}{l}\text { Estaré de acuerdo con los demás sólo superficialmente para evitar } \\
\text { el conflicto'. } \\
\text { 'No debo seguir los pasos de nadie'. } \\
\text { 'Tengo maneras particulares de hacer las cosas que los demás no } \\
\text { pueden entender'. }\end{array}$ \\
\hline Características Cognitivas & \multicolumn{2}{|c|}{$\begin{array}{l}\text { Pensamiento dicotómico: piensan que si obedecen a alguien o siguen sus indicaciones, pierden } \\
\text { total libertad e independencia. }\end{array}$} \\
\hline $\begin{array}{l}\text { Estrategias } \\
\text { sobredesarrolladas }\end{array}$ & \multicolumn{2}{|l|}{$\begin{array}{l}\text { Resistencia pasiva. } \\
\text { Sumisión superficial. } \\
\text { Eludir, trampear las reglas. } \\
\end{array}$} \\
\hline \multicolumn{3}{|c|}{ CURSO DE TRATAMIENTO } \\
\hline \multicolumn{2}{|r|}{ Objetivos } & Técnicas \\
\hline \multirow{3}{*}{$\begin{array}{l}\text { Establecer una relación } \\
\text { terapéutica colaborativa }\end{array}$} & $\begin{array}{l}\text { Comprometer al paciente con el } \\
\text { proceso terapéutico brindándole } \\
\text { cierto control de la terapia }\end{array}$ & $\begin{array}{l}\text { Otorgar un grado de atención y diligencia adecuado a través de } \\
\text { preguntas constantes y retroalimentación terapéutica. } \\
\text { Identificación y evaluación de las creencias distorsionadas } \\
\text { acerca de que lo controlan aportando evidencia de que el } \\
\text { tratamiento es un ejemplo de lo contrario. }\end{array}$ \\
\hline & $\begin{array}{lll}\text { Reducir la ambivalencia } \\
\text { manejando adecuadamente la } \\
\text { confrontación }\end{array}$ & $\begin{array}{l}\text { Diálogo socrático y análisis coste - beneficio: para la } \\
\text { identificación y reducción de la ambivalencia del paciente. }\end{array}$ \\
\hline & $\begin{array}{l}\text { Evitar las luchas de poder con el } \\
\text { paciente }\end{array}$ & $\begin{array}{l}\text { Redacción en colaboración mutua reglas claras acerca de los } \\
\text { horarios, el pago y la duración del tratamiento asegurándose de } \\
\text { que el paciente entiende y está de acuerdo con cada uno de los } \\
\text { puntos establecidos. }\end{array}$ \\
\hline $\begin{array}{l}\text { Entrenar al paciente en } \\
\quad \text { asertividad }\end{array}$ & $\begin{array}{l}\text { Ayudar al paciente a convertir sus } \\
\text { expresiones de ira en algo abierto } \\
\text { y más funcional }\end{array}$ & $\begin{array}{l}\text { Solicitar opiniones al paciente sobre cómo va la terapia y con } \\
\text { respecto a algún cambio que quiera realizar. }\end{array}$ \\
\hline \multirow{2}{*}{$\begin{array}{l}\text { Favorecer la auto- } \\
\text { observación y el } \\
\text { autocontrol }\end{array}$} & $\begin{array}{l}\text { Ayudarlos a tomar conciencia de } \\
\text { los cambios afectivos que } \\
\text { experimentan en relación a los } \\
\text { demás para acceder a sus } \\
\text { pensamientos automáticos }\end{array}$ & $\begin{array}{l}\text { Técnica de automonitoreaje: identificar cómo sienten la ira, los } \\
\text { enojos y otros estados emocionales para acceder a las } \\
\text { creencias subyacentes. } \\
\text { Registro de pensamientos automáticos después de experimentar } \\
\text { una emoción intensa para comprender la conexión entre ambos. }\end{array}$ \\
\hline & $\begin{array}{l}\text { Alentarlos a observar y evaluar sus } \\
\text { expresiones de ira }\end{array}$ & $\begin{array}{l}\text { Analizar y registrar la propia postura, inflexiones de voz, lenguaje } \\
\text { corporal y visual. } \\
\text { Posicionarse más allá de la experiencia propia y observar los } \\
\text { signos que muestran que los demás se ofenden y/o pierden el } \\
\text { interés en ellos. }\end{array}$ \\
\hline \multirow[b]{2}{*}{$\begin{array}{l}\text { Entrenar al paciente en } \\
\text { habilidades sociales y } \\
\text { comunicación }\end{array}$} & $\begin{array}{l}\text { Ayudar al paciente a entender los } \\
\text { limites que hay en la comunicación }\end{array}$ & $\begin{array}{l}\text { Confección de lista sobre buenas habilidades de interacción } \\
\text { social y determinación de las áreas a desarrollar. }\end{array}$ \\
\hline & $\begin{array}{l}\text { Enseñar al paciente a expresarse } \\
\text { de manera más respetuosa }\end{array}$ & $\begin{array}{l}\text { Role play en la sesión para practicar no elevar el tono de voz, } \\
\text { detenerse antes de responder para examinar qué es lo que iba a } \\
\text { decir, detenerse para que los demás respondan. } \\
\text { Empleo de la misma técnica como tarea fuera de las sesiones. }\end{array}$ \\
\hline \multirow{2}{*}{ Gestionar y evaluar la ira } & $\begin{array}{l}\text { Explorar y modificar las creencias } \\
\text { de 'venganza justa' y de control }\end{array}$ & $\begin{array}{l}\text { Registro y cuestionamiento de creencias nucleares y su relación } \\
\text { con las expresiones emocionales asociadas para reemplazarlas } \\
\text { por nuevas creencias más funcionales. }\end{array}$ \\
\hline & $\begin{array}{l}\text { Evaluar si las respuestas } \\
\text { emocionales hacia los demás son } \\
\text { asertivas }\end{array}$ & $\begin{array}{l}\text { Técnica de coste - beneficio: ayuda a identificar las ventajas y } \\
\text { desventajas de seguir manteniendo o cambiar las reacciones } \\
\text { impulsivas. }\end{array}$ \\
\hline
\end{tabular}




\section{REFERENCIAS}

American Psychiatric Association (1995). Manual diagnóstico y estadístico de los trastornos mentales. Barcelona: Masson.

Arntz, A. (2005). El trastorno límite de la personalidad. En A.T. Beck, A. Freeman, D.D. Davis y otros (Autores) Terapia cognitiva de los trastornos de personalidad (pp. 219-248). Buenos Aires: Paidós Ibérica.

Beck, A.T. \& Beck, J.S. (1991). The Personality Belief Questionnaire. Bala Cynwys: Beck Institute for Congnitive Therapy and Research.

Beck, A.T. (1963). Thinking and depression: I. Idiosyncratic content and cognitive distortions. Archives of General Psychiatry, 9: 324-344.

Beck, A.T. (1964). Thinking and depression: II. Theory and Therapy. Archives of General Psychiatry, 9: 561-171.

Beck, A.T. (1967). Depression Clinical, Expermiental and Theoretical Aspects. Nueva York: Harper \& Row.

Beck, A.T. (1976). Cognitive Therapy and the Emotional Disorders. Nueva York: International Universities Press.

Beck, A.T., Emery, G. \& Greenberg, R.L. (1985). Anxiety Disorders and Phobias. A Cognitive Perspective. Nueva York: Basic Books.

Beck, A.T., Freeman, A., Davis, D.D. y otros (2005). Terapia cognitiva de los trastornos de personalidad. Buenos Aires: Paidós lbérica.

Beck, A.T., Rush, A.J., Shaw, B.F. \& Emery, G. (1979). Terapia cognitiva de la depresión. Bilbao: Desclée de Brouwer.

Beck, J.S. (1995). Terapia Cognitiva. Conceptos Basicos y Profundizacion. Barcelona: Gedisa

Clark, L.A. (1993). Manual for the Schedule for Nonadaptive and Adaptive Personality. Mineapolis: University of Minnesota Press.

D'Zurilla, T.J. \& Goldfried, M.R. (1971). Problem solving and behavior modification. Journal of Abnormal Psychology, 78: 107-126.

Davis, D. (2005). El trastorno narcisista de la personalidad. En A.T. Beck, A. Freeman, D.D. Davis y otros (Autores) Terapia cognitiva de los trastornos de personalidad (pp. 275-304). Buenos Aires: Paidós Ibérica.

First, M.B., Spitzer, R.L., Gibbon, M. \& Williams, J.B.W. (1995). The Structured Clinical Interview for DSM-III-R Personality Disorders (SCID-II): Part I. Description. Journal of Personality Disorders, 9:83-91.

Fleming. B. (2005). El trastorno de la personalidad por dependencia. En A.T. Beck, A. Freeman, D.D. Davis y otros (Autores) Terapia cognitiva de los trastornos de personalidad (pp. 305-330). Buenos Aires: Paidós Ibérica.

Fleming. B. (2005). El trastorno histriónico de la personalidad. En A.T. Beck, A. Freeman, D.D. Davis y otros (Autores) Terapia cognitiva de los trastornos de personalidad (pp. 249-274). Buenos Aires: Paidós Ibérica.

Freeman, A. \& Davis, D. (2005). El trastorno antisocial de la personalidad. En A.T. Beck, A. Freeman, D.D. Davis y otros (Autores) Terapia cognitiva de los trastornos de personalidad (pp. 193-218). Buenos Aires: Paidós Ibérica.

Fusco, G. (2005). El trastorno pasivo-agresivo de la personalidad. En A.T. Beck, A. Freeman, D.D. Davis y otros (Autores) Terapia cognitiva de los trastornos de personalidad (pp. 381-402). Buenos Aires: Paidós Ibérica.

Gilbert, P. (1989). Human Nature and Suffering. Hillsdale: Erlbaum.

Hyler, S.E. \& Rieder, R.O. (1987). PDQ-R: Personality Diagnostic Questionnaire-Revised. Nueva York: New York State Psychiatric Institute.

Ingram, R.E. \& Hollon, S.D. (1986). Cognitive therapy for depresión from an information processing perspective. En
R.E. Ingram (comp) Information prossecing approaches to clinical psychology (pp. 281-284). Nueva York: Academic Press.

Kagan, J. (1989). Temperamental contributions to social behaviour. American Psychologist, 44 (4): 668-674.

Klein, M.H., Benjamin, L.S., Rosenfeld, R., Treece, C., Husted, J. \& Greist, J.H. (1993). The Wiscoin Personality Disorders Inventory: Development, reliability, and validity. Journal of Personality Disorders 7: 285-303.

Livesley, J.R. (1990). Dimensional Assessment of Personality Pathology -Basic Questionnaire- (no publicado). University of British Columbia.

Loranger, A.W., Susman, V.L., Oldham, J.M. \& Russakoff, L.M. (1987). The Personality Disorder Examination: A preliminary Report. Journal of Personality Disorders, 1: 1-13.

Mahoney, M. (1984). Behaviorism, cognitivism, and human change processes. En M. A. Reda \& M. Mahoney (comp) Cognitive prysocherapies: Recent developments in theory, research, and practice (pp. 3-30). Cambridge: Ballinger.

Millon, T. \& Davis, R. (1998). Trastornos de la personalidad. Más allá del DSM-IV. Barcelona: Masson.

Millon, T., Millon, C. \& Davis, R.D. (1994). Millon Clinical Multiaxial Inventory-III. Mineapolis: National Computer Systems.

Morrison, A. \& Renton, J. (2005). Los trastornos esquizoides y esquizotipicos de la personalidad. En A.T. Beck, A. Freeman, D.D. Davis y otros (Autores) Terapia cognitiva de los trastornos de personalidad (pp. 167-192). Buenos Aires: Paidós Ibérica.

Obst Camerini, J. (2008). La Terapia Cognitiva. Integrada y actualizada. Buenos Aires: CATREC.

Padesky, C.A. \& Beck, J.S. (2005). El trastorno de la personalidad por evitación. En A.T. Beck, A. Freeman, D.D. Davis y otros (Autores) Terapia cognitiva de los trastornos de personalidad (pp. 331-358). Buenos Aires: Paidós Ibérica.

Pfohl, B., Blum, N., Zimmerman, M. \& Stangl, D. (1989). Structured Interview for DSM-III-R Personality (SIDP-R). lowa City: University of lowa, Department of Psychiatry.

Pretzer, J. (2005). El trastorno paranoide de la personalidad. En A.T. Beck, A. Freeman, D.D. Davis y otros (Autores) Terapia cognitiva de los trastornos de personalidad (pp. 143-166). Buenos Aires: Paidós Ibérica.

Simon, K.M. (2005). El trastorno obsesivo-compulsivo de la personalidad. En A.T. Beck, A. Freeman, D.D. Davis y otros (Autores) Terapia cognitiva de los trastornos de personalidad (pp. 359-380). Buenos Aires: Paidós Ibérica.

Steiner, J.L., Tebes, J.K., Sledge, W.H. \& Walker, M.L. (1995). A comparison of sreuctured clinical interview for DSM-III-R and clinical diagnoses. Journal of Nervous and Mental Disease, 183 (6): 365-369.

Wellburn, K., Coristine, M., Dagg, P., Pontefract, A. \& Jordan, S. (2002). The Schema Questionnaire-Short Form: Factor analysis and relationchip between schamas and symptoms. Cognitive Therapy and Research, 4 (26): 519-530.

Young, J., Klosko, J. \& Weishaar, M. (2003). Schema Therapy. A Practitioner's Guide. New York: Guilford Press.

Young, J.E. \& Brown, G. (1994). Schemma Questionnaire. En J.E. Young (comp) Cognitive therapy for personality disorders: A schema-focused approach (pp. 63-76). Sarasota: Proffesional Resource Exchange.

Young, J.E. (1994). Cognitive Therapy for Personality Disorders: A Schema-Focused Approach. Sarasota: Professional Resource Exchange.

Young, J.E. (2002). Overview of Schema Inventories. Recuperado de http://www.schematherapy.com/id49.htm. 